\title{
Non-Hodgkin's lymphoma risk derived from exposure to organic solvents: a review of epidemiologic studies
}

\author{
Risco de linfoma não-Hodgkin resultante \\ da exposição a solventes orgânicos: \\ revisão de estudos epidemiológicos
}

Marco Antônio V. Rêgo 1,2

\footnotetext{
1 Centro de Estudos da Saúde do Trabal hador - CESAT. Rua Pedro Lessa 123, Canela, Salvador, Bahia 40110-050, Brasil. 2 Instituto de Saúde Coletiva, Universidade Federal da Bahia. Rua PadreFeijó 29, Canela, Salvador, Bahia 40111-170, Brasil. mrego@lognet.com.br
}

Abstract The rate of non-Hodgkin's lymphomas (NHL) has increased around the world during the last decades. Apart from the role of the human immunodefici ency virus (HIV) infection in the devel opment of NHL, exposure to chemical agents like phenoxyacetic pesticides, hair dyes, metal fumes and organic solvents are suspected to be involved. The present revi ew evaluates the results of studies that directly or indi rectly searched for an association between solvent exposure and NHL. The selected studies comprised those published from 1979 to 1997, designed to investigate risk factors for $\mathrm{NHL}$, whether specifically looking for solvent exposure or for general risksin which solvent exposure could be included. In 25 of the 45 reviewed studies (55.5\%), fifty-four statistically significant associations between NHL and solvent exposure related occupations or industries were reported. Statistical si gnificance was more frequentl y shown in studi es where solvent exposure was more accu rately defined. In eighteen of such studies, 13 (72.2\%) defined or suggested organic solvents as possible risk factors for NHL.

Key words Non-Hodgkin's Lymphoma; Occupational Exposure; Solvents; Epidemiology

Resumo A taxa de incidência delinfomas não-Hodgkin (LNH) tem aumentado mundialmente durante as últimas décadas. Além do papel da infecção pelo vírus da imunodeficiência humana (HIV), suspeita-se que a exposi ção a agentes químicos, como os pestici das fenoxia céticos, tinturas de cabelo, fumos metáli cos esolventes orgânicos, esteja envolvida. A presente revisão avalia os resul tados de estudos que direta ou indiretamente procuraram por uma associação entre exposi ção a sol ventes orgâni cos e LNH. Os estudos sel eci onados compreendem aqueles publicados entre 1979 e 1997, que investigam fatores de risco para LNH, sejam os que especificamente analisam sol ventes orgâni cos, sejam os que anali sam ri scos em geral, entre os quais a exposi ção a solventes pudessse estar incluída. Em 25 dos 45 estudos revisados (55,5\%), foram citadas 54 associ ações estatisti camente sign ifi cativas entre LNH e ocu pações relacionadas à exposi ção a solventes. A presença de significância estatística foi evidenciada mais freqüentemente em estudos nos quais a exposi ção a solventes foi definida deforma mai s acurada. Em 18 destes estudos, 13 (72,2\%) definiram ou sugeri ram ser os solventes orgânicos possí veis fatores de risco para os LNH. Palavras-chave Linfoma Não-Hodgkin; Exposição Ocupacional; Solventes; Epidemiologia 


\section{Introduction}

The increasing rate of non-Hodgkin lymphomas (NHL) around the world during the last decades has been exhaustively demonstrated (Linos et al., 1986; Zheng et al., 1992; Devesa \& Fears, 1992; Holford et al., 1992; Hartge \& Devesa, 1992; Costantini et al., 1992; Rabkin et al., 1993; Hartge et al., 1994; Palackdharry, 1994; Scherr \& Mueller, 1996; Seow et al., 1996; Vineis, 1996). On the one hand, some research shows that the increase is mainly a result of viral infection, primarily the human immunodeficiency virus (HIV) infection (Harnly et al., 1988). On the other hand, it has been discussed that this virus had little impact on the NHL incidence trends (Hartge \& Devesa, 1992), and that the increase in NHL was apparent before the arrival of the acquired immunodeficiency syndrome (AIDS) (Holford et al., 1992; Carli et al., 1994). Therefore, this suggests other unknown environmental causes, including chemical exposures (Longo, 1994). Other studies have presented the role of changes in the criteria disease classification and of improvement in diagnosis technology to explain part of the rate growth (Devesa \& Fears, 1992), mainly for the marked increase in extra-nodal NHL in older people (Cozen \& Bernstein, 1994). This explanation does not agree with the findings of Lutz \& Coleman (1994) for primary cerebral lymphoma. This diagnostic bias has been denied (Banks, 1992) and a real annual increase in NHL rates of $4 \%$ in recent years in Britain (Cartwright, 1992) and a recent increase in Denmark (Hjalgrim et al., 1996) have been demonstrated. Among the chemical exposures, there are several agents suspected of being involved in the development of NHL (Blair et al., 1992; Pearce \& Bethwaite, 1992; Vineis, 1996). Some examples are the phenoxyacetic pesticides, hair dyes, metal fumes and organic solvents. The goal of the present review is to evaluate the results of these studies which directly or indirectly looked for an association between organic solvent exposures and NHL.

\section{Methods}

The sel ected studies included those designed to investigate risk factors for $\mathrm{NHL}$, whether the main objective was specifically to look for solvent and NHL relationship or to find general risks, from which solvent exposure could appear (Table 1). In the latter ones, exposure to organic solvents was derived from the information of the occupation or the industry in which the study subjects were enrolled. Therefore, studies whose main objectives were to study general mortal ity patterns, conducted within particular workers' cohorts, like mechanics, painters, printers, dry cleaners, refinery, petrochemical, chemical and rubber workers were not selected, even though some of them could have investigated the relationship of interest in this review. In the same way, the studies linking all occupations and all causes of disease or death, those focusing on $\mathrm{NHL}$ and the role of other specific exposures such as pesticides, smoking, sun light, etc., and those involving children also were not reviewed. Studies that had a further re-analysis, and released a new publication were evaluated again. It is also important to note that most selected studies were written in English language and were published from 1979 to January/ 1997. The method of selection was based on the linkage of the words lymphoma and occupational, environmental or solvent exposure using MEDLINE data from 1966 to 1997. The search was complemented by looking for other studies cited by the authors of the previously selected investigations.

\section{Results}

An observation based on a clinical case series was done in a community composed of 117 Caucasian individuals, from 1968 to 1974 (Capurro, 1979). In that area, where a chemical plant was located, solvent exposure was measured in the environment and detected in $20 \%$ of the visits. Also, some solvents like methyl isobutyl ketone, benzene, chloroform and trichloroethylene were detected in the blood of the residents. Twenty three cases of cancer were listed, eight of them were Iymphoma. Considering specifically the three deaths due to lymphosarcoma in this six year period, the relation between observed and expected cases was $3 / 0.0187=160$ fold.

The first epidemiologic study relating NHL and occupations with potential exposure to solvents was conducted using death certificates of New York State from 1950 to 1969, excluding New York City (Vianna \& Polan, 1979). It was a cohort mortality study in which all male deaths with age 20 and over, among individuals within 14 benzene-related occupations were analyzed. The authors found 146 reticulum cell sarcomas (RCS) and 353 lymphosarcomas (LS), compared them with the same diseases in the general population and had the following findings: $\mathrm{RCS}$, relative risk $(\mathrm{RR})=1.6$; 
LS, RR $=2.1$. Among subjects 45 years old and over, within the seven occupations for which age distributions were available, the number of deaths observed was significantly higher than the number of deaths expected for the two types of Iymphoma: RCS, observed/ expected $(O / E)=1.7(p<0.01)$ and LS, O/E =2.1 $(p<0.01)$. These findings were discussed and criticized for the way Vianna \& Polan (1979) had gotten the information about occupations from both death certificates and the U.S. decennial census. It was said that these sources are incomparable with each other and that they should have calculated proportionate mortal ity ratios, based only on occupation as defined on the death certificates (Enterline, 1979).

The age-adjusted mortality rates of NHL in 3,056 counties of the United States between 1950 and 1975 were verified utilizing an ecological design (Cantor \& Fraumeni Jr., 1980). It showed suggestive associations in a multiple regression analysis between $\mathrm{NHL}$ rates among white males and five industrial groups, including printing and publishing (significant at $p<$ 0.025), petrochemicals and rubber products. They did not find an association for other potential solvent-related industries such as furniture, machinery and electrical.

The first study which directly looked for the relationship between lymphoma and exposure to solvents (among other exposures) was performed in Sweden (Hardell et al., 1981). They studied all 169 men admitted to the Department of Oncology in Umea with 109 diagnosed NHL and 60 Hodgkin's disease (HD), and eight controls matched by age, sex and residence for each living case and 10 for each deceased case matched also by year of death, from the National Population Registry. Analysis of high grade and low grade exposure produced an odds ratio $(O R)=2.8$ (1.6-4.8) and an $O R=1.2$ (0.5-2.6), respectively. Exposure to styrene, trichloroethylene, perchloroethylene and benzene among the high grade exposed individuals gave greater risk than exposure to other organic solvents, OR =4.6 (1.9-11.4). A modifying effect was found when combined exposure to organic solvents and phenoxy acids, OR $=11.2$ (3.2-39.7) and chlorophenols (eight exposed and no exposed controls) were analyzed.

These data were reanalyzed (Hardell et al., 1994) and the authors found the following results: carpenter: 13 exposed cases/ 36 exposed controls, OR =1.1 (0.6-2.4); mechanic: 5/ 7, OR $=2.5$ (0.7-9.6); motor mechanic: $7 / 20$, OR $=1.3$ (0.5-3.4); all organic solvents: $45 / 88, O R=2.4$ (1.4-3.9); high grade exposure: $31 / 50, O R=2.9$ (1.6-5.6); low grade: $14 / 38, \mathrm{OR}=1.8(0.8-3.8)$; benzine: $3 / 1, \mathrm{OR}=2.8$ (1.8-730); thinner: $11 / 14$, OR =3.4 (1.4-10); trichloroethylene: $4 / 4$, OR = 7.2 (1.3-42); turpentine: $5 / 7, \mathrm{OR}=3.3$ (0.9-17); white spirit: $12 / 20, \mathrm{OR}=3.2$ (1.3-8.3); degreaser: $7 / 4, \mathrm{OR}=11$ (2.9-72); multivariate analysis high grade OR =3.5 (1.7-7.1); low grade, OR = 1.1 (0.5-2.7); organic solvents (for lymphocytic and well differentiated NHL), OR =2.9 (1.3-6.6).

The mortality patterns of workers were defined in two styrene-butadiene rubber (SBR) plants with specific focus on hematopoietic and lymphatic malignancies (Meinhardt et al., 1982). It was a retrospective cohort mortality study that received information from 1,662 individuals $(34,187 \mathrm{p} / \mathrm{y})$ in plant $A, 1,094$ individuals in plant $B(19,742 \mathrm{p} / \mathrm{y})$ that gathered information about butadiene, styrene and benzene levels in the workplaces. Only white males with at least six months of non-management and non-administrative employment were included in their analysis. They found standard mortality ratio $(\mathrm{SMR})=155$ (plant $\mathrm{A}$ ) and 78 (plant B) for lymphatic and hematopoi etic tissues in general (International Classification of Diseases - ICD 220-205) and SMR = 181 (plant A) and 132 (plant B) for lympho and reticulosarcoma (ICD 200). These excesses in mortality were not statistically significant. The authors concluded that their findings continue to suggest that the production or manufacturing of SBR may be associated with an excess of lymphatic and hematopoietic neoplasms.

A hospital-based case-control study conducted in Italy did not find positive results for industries (Franco \& Ponte, 1983). In the chemical and pharmaceutical industry there were four exposed cases (EC), OR $=0.16$; textiles, shoes and leather, 21 EC, OR =0.50; paper and printing, three $E C, O R=0.90$ and rubber and plastics, three $E C, O R=0.33$. An important association was seen for woodworkers, with 14 $\mathrm{EC}$ and $\mathrm{OR}=5.55$ (2.39-12.85). The authors discussed the role of some agents used during the manufacture and treatment of wood, like benzene, chlorophenols, phenoxyacids and coal tar derivatives. In this study, cases were 282 NHL and 387 HD (347 male and 322 female patients of both sexes admitted to the Clinica Medica A. Ferrata - University of Pavia, from 1969 to 1980 , diagnosed as malignant Iymphoma. Controls were 757 male and 588 female patients admitted to an internal medicine unit in Pavia from 1975 to 1980 . Occupations were defined as proposed by the Annuario Statistico I taliano. The analysis did not consider the NHL and the HD separately.

Based on the National Cancer Registry in England and Wales, a case-control study was 
conducted with malignant lymphomas in male road transport workers aged 15 and over, diagnosed from 1973 to 1977 . Control individuals were randomly chosen from other cancer patients, matched $1: 1$ by age, sex and region of residence. Among all Iymphomas (426), 256 were recognized as NHL (ICD 200 and 202). The results did not reach statistical significance, and the authors implied some positive findings to possible exposure to exhaust fumes. Thus, the following results were reported: ICD 200: drivers of buses and coaches, OR $=1.16$ (0.60-2.26); drivers of other road passenger vehicles, OR $=0.95$ (0.48-1.88); drivers of road goods vehicles, $\mathrm{OR}=0.93$ (0.71-1.22); bus conductors, OR $=0.57$ (0.12-2.25); lorry drivers' mates, etc.: no cases; ICD 202: drivers of buses and coaches, OR =1.63 (0.62-4.52); drivers of other road passenger vehicles, OR $=1.67$ (0.684.32); drivers of road goods vehicles, $O R=0.90$ (0.63-1.28); bus conductors, OR $=2.67$ (0.6415.6); lorry drivers' mates, etc.: no cases (Balarajan, 1983; Balarajan \& McDowall, 1983).

All new cases of lymphoid malignancies diagnosed between October/ 1979 and December/ 1981 were selected among adult residents in six health districts in Yorkshire Health Region. There were 81 male and 77 female NHL, 48 HD, 66 chronic lymphocytic leukemia and 13 acute lymphoblastic leukemia cases. It was a hospital-based case-control study where the control group was performed by non-cancer hospital patients (162 male and 154 female for NHL cases), matched for age, sex and geographic area in a ratio of 1:1. Past occupations and selected exposures were analyzed and the following results were observed: occupational exposure to solvents (excluding benzene), OR = $1.52(0.70-3.26)$ male and OR $=7.71$ (1.2447.93) female; petroleum industries, $O R=4.21$ (0.54-32.79) male; solvent use as hobby, OR = 1.39 (0.30-6.46) male; benzene, OR $=0.49$ (0.212.0) male; petrol products, $O R=0.59(0.25$ 1.39) both sexes; hair sprays, OR $=1.49$ (0.752.95) female; hair sprays, $O R=4.67$ (1.50-13.63) female $>65$ years old. The number of exposed cases was not referred, nevertheless it can be inferred that they were small by looking at the large confidence intervals, including those statisticaly significant associations were seen among women (Bernard et al., 1984).

A new paper with the complete Yorkshire study data set was published including cases diagnosed until December/84 (Cartwright et al., 1988). The final rate between controls and cases was 1.7. At that time, 437 cases ( 244 males and 193 females) and 724 controls were studied. NHL cases were confirmed by the Regional
Histopathology Lymphoma Panel. The new analysis showed the following results: solvents, OR =1.2 (0.9-1.5); glues, OR =1.8 (1.2-2.6); and other non-significant associations in solvent related occupations, however with no mentioned OR value: chemical workers, printers, painters and decorators.

A population-based case-control study with all incident cases of myeloproliferative and Iymphoproliferative diseases was done in Tasmania, Australia, with data from 1972 to 1980. Within that population there were 798 total cases, including 241 NHL ( 125 male and 116 female). The control group was selected, based on a 1:1 ratio. Individuals were mainly asked for both occupational and familial histories. Based on a few cases, it was seen a strong association between male foundry workers and $\mathrm{NHL}, \mathrm{OR}=8.0$ (1.07-356.0). There were five exposed cases and no exposed controls among female hairdressers (Smith \& Lickiss, 1980; Giles et al., 1984)

A population-based case-control study evaluated environmental chemical exposures as risk factors for leukemia and NHL (Everett et al., 1985). The selected subjects were 1,200 men with these diseases and controls by random dialing and from social security files. Exposure evaluation included a series of chemicals which are seen in the workplace or home. For $\mathrm{NHL}$, the following odds ratio were noted for sol vent-related exposures: lacquers/varnishes, OR =1.24 ( $p<0.1)$; engine exhaust, OR $=1.26(p<0.05)$; hydrocarbon coats, OR $=1.67$ $(p<0.1)$; hydrocarbon cleaners, $O R=2.13$ $(p<0.001)$; paint aerosols, OR $=1.28(p<0.1)$ and gasoline as a cleaning agent, $O R=1.29$ $(p<0.05)$.

Information was recorded from patients admitted to the Hospital of Varese, Italy to treat NHL and HD during 1984 and from non-cancer patients who were admitted to the same hospital. The eligibility criteria included living in that city for at least 15 years. There were $43 \mathrm{NHL}$ (14 male and 28 female) and 46 HD cases and 89 controls. Some occupations were considered "exposed occupations": professors, farmers, metal-mechanics, chemists and textile workers. Their results showed an increased risk for metal-mechanics, $R R=1.98$ (0.75-5.20) based on 13 exposed cases and for chemists, RR =1.01 (0.27-3.74) based in four exposed cases. In this hospital-based case-control study the selected cases were neither prevalent nor incident cases in a defined period of time, and it does not seem that those cases have been representative of either general population or hospital population (Binaschi et al., 1985). 
A death certificate-based case-control study of NHL and occupations with 501 and 569 male cases and controls, respectively, was carried out in North Carolina (Schumacher \& Delzell, 1988). They observed an increased risk for occupations in rubber, plastics and synthetics' industries only for whites, based on four exposed cases and no exposed controls. Associations were neither seen for occupations with potential benzene exposure nor for chemical drugs and paint industries.

Two hundred and two male cases (ICD 200202), age 20 and over and 666 age matched male controls, excluding smoke-related cancers and prostate cancer were selected from Missouri Cancer Registry between 1984 and 1985. Risk excess was found only among printers, OR =2.72 (0.96-7.69). No associations were observed with other sol vent-related occupations (Brownson \& Reif, 1988).

Another Swedish study was specifically designed to investigate the risk of $\mathrm{NHL}$ among men occupationally exposed to organic solvents. It was a hospital-based case-control study, where the case group was performed by a consecutive series of 167 men admitted between 1978-1981, in the Department of Oncology, University Hospital of Lund (Sweden) and the control group by 130 healthy men selected from the population registry. Exposure was defined by "handling organic solvents for at least one year daily". Categorization in five year age groups showed an ORM-H =3.3 (1.9-5.8); for supra-diaphragmatic tumors, OR $=6.5$ (3.213.3) and for other lymphoma presentations, OR =2.3 (1.3-4.3) (Olsson \& Brandt, 1988).

In Hancock County, Ohio, all white male residents aged 15 or more who died during 1958-1983 with malignant lymphoma were enrolled in a case-control study. There were 61 NHL and 15 HD, who were matched with other deceased individuals, chosen through a stratified random sample by age at death and year of death, in a proportion of $4: 1$. No associations were found with solvent-related occupations or industries. In addition, with the small number of subjects and despite the rush to complete study, the authors discussed the limitations of such a death certificate-based case-control study, mainly because of the inaccuracies in the cause of death and the lack of occupational and industrial information (Dubrow et al., 1988).

All white U.S. Navy enlisted men during 1974-1983 were the subjects of a large cohort study (Garland et al., 1988). The unexposed group was performed by the U.S. population provided by SEER (Surveillance, Epidemiology, and End Results). The exposed group was com- posed of 435,425 men/ 3,704,864 person/ years from 80 U.S. Navy occupations. The NHL cases were reviewed by a board of specialists and classified according to the ICD 8th: (200.0, 200.1, 202.0-202.9); ICD 9th: 200.0, 200.1, 202.1, 202.8, 202.9. Sixty eight NHL cases were found in the exposed group. There were five cases among aviation structural mechanics, standard incidence ratio $(\mathrm{SIR})=1.5(0.5-3.5)$ and 1 case among machinery repairmen, $\mathrm{SIR}=1.8$ (0.010.0).

A nested case-control study was conducted within a cohort of 29,139 employed men from two chemical plants between 1940 and 1978 (Ott et al., 1989). The authors were looking for lymphatic and hematopoietic tissue cancers, and among all cases (129), 52 were identified as $\mathrm{NHL}$ from both underlying and contributory causes of death. Controls were selected from the total employee cohort according to a group-matched incidence density sampling in a 5:1 ratio. Elevated odds ratios were seen in the ethanol unit, OR =5.4 (1.5-19.5) based in five cases, and in two maintenance and construction groups, foremen and others, 11 cases, OR = 3.2 (1.4-7.2) and instrument men, OR = 5.2 (1-26.7), three cases. The authors discussed the role of the carcinogenic action of alkyl sulfates which originated from the reaction between alkenes and sulfuric acid to produce ethanol and isopropanol. They also discussed the difficulties in explaining the findings among foremen and others because of their heterogeneity and the lack of trends with employment duration. The authors found an OR = 1.2 (two exposed cases) for less than five years and an OR $=1.6$ (three exposed cases) for more than five years of exposure.

The epidemiology of NHL in north-east I taly was evaluated through a hospital-based case-control study. There were 110 men and 98 women below age 80 with $\mathrm{NHL}$, admitted from June 1983 to M arch 1988 at the Aviano Cancer Center and in all general hospitals in the province of Pordenone. Controls were 215 men and 186 women ages 17-79 with acute disorders, who were from the same hospitals and same catchment area. Exposures to 20 potentially carcinogenic chemical or physical agents were evaluated. For those activities with probable solvent exposure, they found an increased risk for chemical, OR $=1.64(0.88-3.06)$ and petrochemical workers, $\mathrm{OR}=1.83(0.87-3.84)$ and suggested that employment in these industries may increase the probability of the onset of the disease. On the other hand, they had the following negative findings: dye and paint, $\mathrm{OR}=0.72$ (0.36-1.44); plastic resin/glue, OR = 
1.01 (0.46-2.23); benzene/ solvents, $\mathrm{OR}=1.14$ (0.57-2.28) and wood/furniture, OR $=0.66$ (0.37-1.19) (Franceschi et al., 1989).

Another Italian study did not show any association between NHL and a group of selected solvent related occupations and agents (chemical, petrochemical plastic resins/glues, solvents/benzene, oil, dyes/paints, rubber, printing and furniture). It was a hospital-based case-control study which included 153 incident cases of NHL (93 males and 60 females), 69 Hodgkin's disease and 110 multiple myeloma diagnosed in patients aged 15-74, admitted to a network of teaching and general hospitals in the greater Milan area, from 1983 to 1988. Controls were 396 patients admitted to the same hospitals with acute conditions (La Vecchia et al., 1989).

Data from a previously selected control group for two other studies, from the population registry, were utilized in a new case-control study (Persson et al., 1989). Cases were 106 NHL ( 66 men and 40 women) and 54 HD cases, obtained from the Department of Oncology at Örebo Medical Centre Hospital, Sweden. They were diagnosed between 1964 and 1986, and were still alive in 1986, ranging in age from 20 80 years. Both groups answered posted questionnaires. In this hospital-based case-control study, solvent exposure was classified by five levels of intensity, for at least one year, taking into consideration a latency time of five to 45 years before diagnosis and time of selection for controls. There were seen some important increased risks: solvents, OR $=2.0$ (33/50 exposed cases/controls); thinner, OR =2.7 (15/16); white spirit, OR =3.1 (13/12); trichloroethylene, OR = 1.5 (8/ 14); styrene, OR =8.0 (3/1); painters, OR $=(3 / 0)$; plastic/rubber chemicals, OR $=2.5$ (9/10); carpenter/ cabinet makers, OR $=3.1$ (10/9). The confidence intervals were not cited. The logistic OR =1.9 (90\% 1.1-3.2) and OR =2.8 (90\% 1.1-7.1) apply to solvent exposure to carpenters and cabinet makers, respectively.

A new study was conducted (Persson et al., 1993) with the same planning. Cases were 93 NHL and 31 HD occurred in men living in Östergötland, Jönköping and Kalmar counties, obtained from the Regional Cancer Registry at the University Hospital in Linköping, diagnosed between 1975 and 1984, alive in 1986, and aged 20-80. At this time, only men were studied. Two hundred and four referent individuals were drawn from the population registry. In that study, occupational exposure to solvents revealed an OR $=1.2$ (28/53 exposed cases/ exposed controls) and an $\mathrm{OR}=1.7$ and an ORlog =1.1 (0.6-2.2) (24/34), when intensity category levels 2-5 X 0- 1 were analyzed; white spirit, OR =1.6 (14/20); aviation gasoline, OR = 3.0 (4/3). For non-occupational exposure was seen an OR $=3.4(3 / 2)$. Carpenters and cabinet makers had an OR $=1.0$ and an ORlog $=0.9$ (0.4-2.1) (11/25), which means a conflicting result in regards to the former investigation.

A population-based case-control study was primarily designed for looking for associations between NHL occurrence and specific agents in farm practices. Cases were 201 men aged 21 or older in 66 counties of eastern Nebraska, diagnosed with NHL from 1983 to 1986. They were identified through the Nebraska Lymphoma Study Group Registry and area hospitals and physicians, and reviewed by a pathologist. Controls were 725 subjects selected from residents of the same area, matched by age, race and vital status. Both groups were interviewed by telephone. For exposure to chlorinated hydrocarbons an $\mathrm{OR}=1.9(0.8-2.3)$ was observed (Weisenburger et al.,1990).

The relationship of occupational risks and hematological malignancies development were evaluated through a hospital-based case-control study (Pasqualetti et al., 1991). They selected $108 \mathrm{NHL}$ within 620 neoplasm hospital patients aged 24-85, and 2:1 sex and age matched hospital controls with "medical diseases", except cancer and congenital diseases, from the same area as the cases. On one hand, the authors found statistically significant associations between hematological malignancies in general and industrial activities, OR $=2.97$ (1.98-4.46), exposure to aromatic hydrocarbons, OR =2.15 (1.39-3.32), dyes and inks, OR = 1.28 (1.11-1.99), mineral oils, OR $=2.59$ (1.753.84) and paints and related products, OR = 1.55 (1.06-2.26). On the other hand, when they analyzed specifically the NHL subset, only an association with mineral oils was seen, OR = 3.4 (1.65-7.38). They have found a lack of association between NHL and other potential exposures to solvents such as auto mechanics, railroad workers, or specific exposures to cetonas, aliphatic hydrocarbons, chlorinated hydrocarbons, and dye, paints and inks.

With the Danish Cancer Registry data, individual s aged 20-64 from 1970 (census data on industry and occupations) were followed up for cancer incidence until 1980 (Skov \& Lynge, 1991). NHL cases were 1,167 in men and 849 in women during that period, distributed among 492 male and 447 female occupational groups. Statistically significant associations were not obtained, however it was suggested that potential exposure to chemical agents may be implicated in the increased risk for NHL based 
mainly in the findings of wood working (male), $\mathrm{RR}=1.15$ (0.87-1.52); chemists (female), RR = 2.32 (0.85-5.04) and hairdressers (female), RR = 2.01 (0.81-4.14).

Incident cases of NHL (572) and leukemia (520) among white men diagnosed between 1980 and 1983 in lowa and Minnesota were selected for a population-based case-control study in the USA (Linos et al., 1991). Diagnoses were reviewed by a panel of pathologists. Controls were frequency-matched by year of birth, vital status, state of residence and year of death, by a two-stage random digit dialing $(\varangle 65$ years) and from Health Care Finance Administration (65 years). Questionnaires were applied to study subjects or their next-of-kin, and exposure was defined as the location of residence within 3.2 and within $0.8 \mathrm{Km}$ from a factory. Among the first ones, were factories where organic solvents are handled. In the chemical plant there were $18 \mathrm{EC}, \mathrm{RR}=1.0(0.6-1.9)$, in the petroleum industry, $14 \mathrm{EC}, \mathrm{RR}=1.5$ (0.73.2) and in the rubber plant, $11 \mathrm{EC}, \mathrm{RR}=0.6$ (0.3-1.3).

In an ecological study, information about lympho-hematopoietic neoplasm incidence in 22 counties in the UK (1984/ 1988) was crossed to car ownership by county (1981) from Great Britain Population Census and Transport Statistics data. There were 2,415 low grade and 2,550 high grade NHL within a total of 21,072 neoplasms. The Spearman rank correlation coefficients showed a statistically significant association between low grade NHL incidence and cars per household $(0.66 p<0.001)$ and cars per thousands $(0.68 p \measuredangle 0.001)$. No association was seen for high grade NHL. The author called for reservation about these preliminary outcomes from data based on geographical correlation, but implied that if these are true, the non-occupational low exposure to benzene from petrol combustion and petrol evaporation may be playing an important role (Wolff, 1992).

A hospital-based case-control study, where cases were all newly N HL diagnosed patients, from 1980 to 1982 was carried out among residents of the Boston Metropolitan Area who were treated in one of nine participating hospitals (Scherr et al., 1992). The control group was composed of individuals matched by age, sex, town and precinct of residence, randomly selected from the town residence list. Cases were made up of 152 males and 151 females, with controls for the 303 individuals. Diagnoses were reviewed by a panel of pathologists, who utilized Rappaport (modified) and International Working Formulation NHL classifications.
Questionnaires were directly applied to cases (67\%), to cases' proxies (31\%) and to cases' guardians (2\%). No information was mentioned regarding distribution of these interviews within the control group. The main results, related to solvent exposures were: gasoline or kerosene, OR =1.0 (0.6-1.7); benzene, OR =1.2 (0.5-2.6); chorinated solvents, $\mathrm{OR}=1.2(0.8-1.8)$; metal industry, OR = 1.2 (0.6-2.5); machinery, OR = 0.8 (0.4-1.4); shipbuilding, auto, $O R=1.0$ (0.6$1.7)$; chemicals, drugs and paints, $O R=0.3$ (0.1$0.9)$; leather, OR =2.1 (0.9-4.8); dry cleaning, OR =1.6 (0.6-4.0); painter and plasterer, OR = 6.0 (0.9-38); carpenter, brick and stone mason, plumber and roofer, OR = 12.0 (2.0-72); airplane or auto mechanic, gas station attendant, $\mathrm{OR}=1.4$ (0.6-3.6).

Cancer incidence from 1971 to 1984 was defined using the Swedish Cancer-Environment Registry, with occupational information from the 1970 census (Eriksson et al., 1992). At the end of the follow up the authors got 1,082 NHL cases (830 men 252 women), 317 HD and $684 \mathrm{MM}$ classified according the ICD 7th 200203. Among all occupational groups with potential exposure to solvents, carpenters (149 OC) yielded a SIR = 1.2 (1.0-1.5).

A nested case-control study was carried out with fatal lymphatic and hematopoietic malignancies which occurred in male workers of eight North American styrene-butadiene plants between 1943-1982. The original cohort had 13,686 workers and yielded $15 \mathrm{NHL}$ cases among 59 lymphohematopoietic cancers. The control group was performed by 193 individuals, matched by year of hire, date of death, age and duration of work, selected from the same cohort with causes of death other than neoplasms. A job exposure matrix (JEM) was constructed by a panel of four chemical engineers who classified the exposure to styrene and to butadiene using data from personal records. For styrene exposure an OR =1.39 (0.13-3.92) was seen for lymphosarcoma and an $\mathrm{OR}=2.42$ (0.50-11.6) for other lymphomas, which include myeloma (Santos-Burgoa et al., 1992). Epidemiologic studies pertaining to the possible relation between exposure to 1,3-butadiene and the occurrence of Iymphatic and hematopoietic cancer among styrene-butadiene rubber and butadiene production workers were reviewed. In the aggregate data, there were 20 observed vs. 17.9 expected deaths from lymphosarcoma cases. In general, it was concluded that there is no support for a causal relationship for such exposures (Cole et al., 1993).

An industry-based case-control study was carried out in Finland (Partanen et al., 
1993). Cases were malignant lymphomas and leukemias notified to the Finnish Cancer Registry, diagnosed in male woodworkers of 35 plants, within a cohort of 7,307 workers, between 1957-1982. Controls ( 52 for the NHL cases) were matched by year of birth and survival/non-survival status in 1983, selected from the same cohort. Only eight NHL cases were found (ICD 200, 202). Individual exposures to solvents and to other agents were reconstructed using a plant/period-specific JEM (cases and controls). Also interviews of persons at the plants were performed and questionnaires were applied (only to cases or their next-ofkin). For unidentified solvents, leukemias and lymphomas pooled (four exposed cases) produced an $\mathrm{OR}=5.62(0.99-32.0)$ and adjustment for formaldehyde exposure showed an OR = 5.07 (0.40-63.5). Two exposed cases and no exposed controls were seen when NHL were analyzed separately.

White men with $\mathrm{NHL}$ reported to the lowa State Health Registry, between 1981 to 1983 and between 1980 to 1982 at a network of hospitals in Minnesota were included in a population-based case-control study (Blair et al., 1993). The 1,245 control individuals were frequency matched with the $622 \mathrm{NHL}$ cases by age, year of death for deceased cases, and state, from random digit dialing, medicare files and listings of death. Questionnaires were directly applied to cases and controls or their surrogates and included information about job titles and industries, which were further evaluated by an industrial hygienist, who decided the probability of exposure (four levels) and intensity of exposure (three levels). The authors concluded that industrial exposures are not a major contributor to the etiology of NHL. Some important findings were: painting/ paper hanging, OR $=1.9$ (0.9-3.8); petroleum refining, OR = 1.6 (0.5-5.8); printing, $O R=1.5$ (0.4-5.1); paints, OR =1.1 (0.9-1.5); asphal t and creosote, $\mathrm{OR}=1.0$ (0.7-1.6); gasoline and diesel exhausts, $\mathrm{OR}=1.0(0.8-1.3)$. This study tried to find a relationship between low and high exposures and sub-types of the disease, classified as follicular or diffuse. It was seen that the risk of NHL rose slightly with increasing levels of exposure to benzene and other solvents. The main results were: benzene, OR =1.1 (0.9-1.4); OR =1.3 (0.91.9) for low level/ follicular; $O R=1.9$ (0.7-5.3) for high/follicular; OR =1.2 (0.8-1.8) for low/ diffuse; OR =1.8 (0.6-5.4) for high/ diffuse; solvents other than benzene OR $=0.9(0.9-1.4)$; OR $=1.4$ (0.9-2.0) for low/ follicular; OR =1.1 (0.4-2.7) for high/follicular; OR =1.0 (0.7-1.5) for low/ diffuse and $O R=2.4$ (1.2-5.0) for high/ diffuse.
A large cohort study linked information about cancer incidence from 1961 to 1979 using the Swedish Cancer-Environment Registry with occupational information from the 1960 census (Linet et al., 1993). There were 4,496 observed cases among employed Swedish men distributed among industrial and occupational categories, which derived from international standards. The most important associations regarding solvent exposure were seen in the shoe repair industry: 23 cases, $S I R=1.8 p<0.05$; shoemakers: 23 cases, SIR $=1.7$ ( $p \varangle 0.05$ ); porcelain and earthenware: 14 cases, $\operatorname{SIR}=1.9(p<0.05)$; furniture maker: 44 cases, $S I R=1.3(p<0.01)$ and lorry drivers: 42 cases, SIR $=1.4$ ( $p<0.01$ ). Other well known solvent related industries and occupations failed to show associations.

The same strategy was applied to study the female workers (Linet et al., 1994). They observed 1,174 cases of NHL in employed Swedish women. At that time, the following results were verified: furniture and finishing industry: four cases, SIR $=1.5$; graphics industry and publishing business: 15 cases, SIR $=0.7$; rubber industry: five cases, SIR = 1.1; chemical industry: nine cases, $\mathrm{SIR}=0.8$; machine and electronics industry: 26 cases, SI R $=0.8$; shoe and leather workers: 10 cases, SIR $=1.4$.

A death certificate-based case-control study (Massoudi, 1994; Massoudi et al., 1997) was done in Kanawha County (West Virginia). Cases were 435 Iymphatic and hematopoietic neoplasms in white male aged 23-96 who had died between 1965-1990. Among them there were 106 NHL (ICD 9th 200, 202) reviewed by a pathologist. Industries and occupations were obtained from death certificates and validated by interviewing next-of-kin. Three categories of exposure were defined: chemical manufacturing workers, those exposed to chemicals at other jobs, and those not exposed. The association between NHL and work in chemical industries was analyzed (chemical workers versus not exposed): crude analysis, OR $=1.52$ (0.82.8); age $<65$ OR $=3.11$ (1.1-8.8); age $65 \mathrm{OR}=$ $0.97(0.5-2.1)$

Another large cohort study was developed in Denmark (Kolstad et al., 1994). The exposed group consisted of 53,720 male workers (584,556 persons/year) employed any time from 1964 to 1988 in 386 reinforced plastic industry and resident in Denmark after 01/ 01/ 70, followed up until 12/31/89. The non-exposed group was composed of individuals from the general population. Exposure to styrene was evaluated using 2,473 personal air samples from work sites during 1964-1970, 1971-1975 and 1976-1988 with the mean styrene levels of 
180, 88 and 43 ppm (1,814 were sampled from companies included in the study). Among the companies with $1-49 \%$ of workers in reinforced plastics production the following results were seen: < 10 years since 1st employment: 19 observed cases (OC), SIR =2.35 (1.42-3.67); 10 years: $17 \mathrm{OC}$, SIR $=1.23$ (0.71-1.98). Among those companies with $50-100 \%$ of workers in reinforced plastics production different results were found: $<10$ years since 1st employment: 2 $\mathrm{OC}, \mathrm{SIR}=0.43$ (0.05-1.57); 10 years: four OC, $\mathrm{SIR}=0.79$ (0.22-2.02). When all companies were evaluated together, SIR was 1.33 (0.961.80 ) with $42 \mathrm{OC}$. The analysis per year of the 1st employment did not show significant findings: 1964-1970, 21 OC, SIR =1.28 (0.79-1.96); 1971-1975, $10 \mathrm{SI} \mathrm{R}=1.19$ (0.57-2.18); 1976-1988, $11 \mathrm{OC}, \mathrm{SIR}=1.64$ (0.82-2.94).

Based on death certificates, a case-control study where cases were $23,890 \mathrm{NHL}$ deaths was done among residents from 24 American states between 1984-1989 (Figgs et al., 1995). There were five non-cancer death controls per case, totaling 119,450 individuals. Cases were classified according to the ICD 9th, categories 200 and 202 (except 202.3 and 202.6). Exposure was defined as industries and occupations obtained from death certificates. Occupations with certain or potential exposure to solvents were stratified for race. For white men, aircraft mechanics had an $\mathrm{OR}=2.5$ (1.1-6.0) with eight exposed cases; farm equipment mechanics, seven exposed cases, OR =2.1 (0.9-5.3); electronic repairs, 12 exposed cases, OR $=2.1$ (1.14.1); miscellaneous electronic and electrical repairs, 10 exposed cases, OR $=2.0(1.0-4.3)$; painters, 65 exposed cases, OR $=0.6(0.5-0.8)$. For black men, only ship/ boat building and repair industry was important in relation to solvent exposure and had seven exposed cases and an OR $=2.9$ (1.1-7.9).

A case-control study in Lyon, France, evaluated cases of hematological malignancies, which included $52 \mathrm{NHL}$ of both sexes, aged 3074 and diagnosed between January/ 1981 and December/ 1987 in two hospitals (Hours et al., 1995). Control subjects were non-cancer and non-occupationally diseased patients, 1:1 matched by sex, age and nationality, from the same hospitals. Occupational exposure to 320 compounds was verified using questionnaires plus evaluation by experts in chemistry and occupational medicine. An OR $=2.1(p=0.23)$ based on 13 exposed cases was seen for exposure to mononuclear aromatic hydrocarbons which include benzene. An OR $=14.86(p<0.01)$ was found for exposure to a mixture of benzene, toluene and xylene (BTX) based in six ex- posed cases. Polynuclear aromatic hydrocarbon had (30 EC), $\mathrm{OR}=0.76$. Exposure to inks $(20 \mathrm{EC})$ yielded an $\mathrm{OR}=2.47(\mathrm{p}=0.02)$ and varnish and paints exposure (sixEC), OR $=2.55$ ( $p$ $=0.08$ ).

In a small cohort mortality study, 338 male employees $(3,813 \mathrm{p} / \mathrm{y})$ of the fleet maintenance division of the DC's Department of Public Works (DPW), employed for at least one year between 1977-1991 were followed up (Hunting et al., 1995). Nine cancers and three lymphatic and hematopoietic deaths (one NHL death) were found. Potential exposure to fuels and solvents was classified as low, medium or high, according to personal records data and DPW and union representatives discussion. The three lymphatic and hematopoietic cancers showed a SMR $=4.22(0.87-12.34)$ and the NHL case, a SM R =2.57 (0.06-14-27).

A very large multicenter retrospective study was conducted within a cohort of Chinese workers (Dosemeci et al., 1994; Travis et al., 1994; Yin et al., 1996). The exposed group was composed of 74,828 workers employed from 1972 to 1987 in 672 factories in 12 Chinese cities and the unexposed were 35,805 workers from 109 factories in the same period and places. They analyzed all available data: work units; job titles; monitoring data; list of row material and factory products; engineering control; personal protective equipment and with them, benzene exposure in parts per million was estimated. Seventeen exposed deaths, $\mathrm{RR}=4.5(1.3-28.4)$ and 20 exposed cases, $\mathrm{RR}=$ 3.5 (1.3-14.9) were found. In this study, the limitation was the lack of homogeneity of the data from too many different plants.

In a nested case-control study in Canada, cases were all male $\mathrm{NHL}$ deaths from a cohort of petroleum workers and controls were selected from the same cohort matched by a decade of birth in a proportion of 4:1 (Schnatter et al., 1996). Of a total of 31 lympho-haematopoietic cancers, eight were N HL. Personal records plus evaluation by experts in industrial hygiene were utilized to estimate benzene and the total hydrocarbon exposures in ppm. No association was found between the low level exposures and mortality by NHL. The size and consequentially the power of this study were seen as important limitations.

Also in Canada, a large registry-based casecontrol study was developed. Lymphoma plus 18 other types of neoplasia were studied to generate a hypothesis about the occupational causes of cancer (Fritschi \& Siemiatycki, 1996). Subjects were 215 men aged 35-70, with a new histologically confirmed NHL diagnosed be- 
tween 1979-1985 and residing in Montreal. The control group consisted of 2,357 other cancer patients, excluding lung cancer, and by 533 individuals sel ected from an electoral list or by random digit dialing. A structured questionnaire plus evaluation by a team of chemists and industrial hygienists were used to define exposure. Exposure was categorized as possible, probable and definite, and the frequency of exposure defined as $<5 \%, 5-30 \%$ and $>30 \%$. The concentration of the agent at the workplace was also analyzed. These three measures were combined, producing three groups: unexposed, non-substantial and substantially exposed. Occupations and industries were also classified. No association was found. There were 20 cases exposed to benzene and classified as the non-substantial exposed group, OR $=0.7(0.4-1.1)$ and six in the substantial exposed group, OR $=0.8(0.3-2.1)$. For solvents in general, classified as low level, there were 26 $E C, O R=0.6$ (0.4-1.0) and for high level exposure, $48 \mathrm{EC}, \mathrm{OR}=0.9$ (0.6-1.3). Among carpenters, there was no case with 1-9 years of exposure and four $E C, O R=0.8(0.3-2.2)$ for those with 10 years or more in that occupation. In the furniture industry: 1-9 years, one EC, OR $=0.4$ (0.1-3.4); 10 years or more: three $E C, O R=1.6$ (0.4-6.1). Finally, among the rubber and plastic workers: $1-9$ years: four $\mathrm{EC}, \mathrm{OR}=3.6(0.9-15.0)$; 10+years: one EC, OR =9.0 (0.6-148.0).

Holly et al. (1997) developed a case-control study. Cases were 312 NHL among homosexual men, and controls were also homosexual men, matched by age within five years and county of residence. Chemical and occupational exposures were evaluated using questionnaires. The authors concluded that among the HIV positive men, occupational exposures were of brief duration and did not account for the development of the NHL cases.

One of the most important studies was developed by Tatham et al. (1997) using data from eight cancer registries in the United States between 1984 and 1988. It was a population-based case-control study, where the $1,048 \mathrm{NHL}$ cases in men were grouped by subtypes defined by a panel of pathologists. There were 185 small cell diffuse Iymphomas; 268 follicular lymphomas and 526 large cell diffuse Iymphomas. Controls were 1,659 individuals matched by date of birth (within five years) through random digit dialing. All individuals were interviewed by telephone. Time of exposure for all jobs with known dates were defined within 10 years and more than 10 years. An OR $=0.91(0.75-1.10)$ was seen for chlorinated hydrocarbons. For solvent exposure, the follow- ing results were found: all NHL subtypes, OR = 1.10 (0.90-1.30); small cell diffuse, $O R=1.60$ (1.10-2.20); small cell diffuse, 9 years of exposure, $\mathrm{OR}=1.50$ (0.99-2.20); small cell diffuse, > 9 years of exposure, OR $=1.70$ (1.10-2.60); small cell diffuse, 10 years since first exposure, OR = 3.00 (1.60-5.80); small cell diffuse, $>10$ years since first exposure, $O R=1.50$ (1.00-2.10); follicular, OR =1.0 (0.79-1.40); large cell diffuse, OR $=0.97(0.79-1.20)$.

\section{Discussion}

In total, 45 studies were reviewed. Twenty one (46.7\%) were conducted in Europe. This issue was a concern mainly in Sweden where eight of these studies were done, in Italy five studies and four in the United Kingdom. In North America, 20 studies (44.4\%) were done in the United States and two (4.4\%) in Canada. The remaining two studies came from Australia and China. Only one study focused exclusively on women. In 25 studies (55.5\%) only men were selected and 19 (42.2\%) included both sexes. This difference could be partially explained by the fact that more male workers have an opportunity to be exposed to organic solvents. Nevertheless, most occupational cancer epidemiologic research has focused on white men. The reasons for excluding women and minorities from consideration in this kind of study are numerous and often legitimate. Small numbers of subjects or events, lower exposures and difficulty in tracing were the reasons most commonly given. However, a general lack of interest or lack of consideration are also possible reasons (Zahm et al., 1994).

Since the outcome of these studies is a rare disease, it was not a surprise that the case-control design had been chosen in 32 studies (71.1\%). Among them, hospital based casecontrol studies were most often conducted, 12 (37.5\%), followed by the populational casecontrol design, nine (28.1\%), death certificatebased, four (12.5\%), nested case-control, four (12.5\%) and registry-based case-control, three (9.4\%). Other designs were 10 (22.2\%) cohort studies, two ecologic (4.4\%) and one clinical case series (2.2\%). The number of cases ranged from one to 23,890 individuals.

In 20 studies (44.4\%), cases of NHL were reviewed by a pathologist or by a panel of pathologists and in 25 (55.6\%) this review was not done. The objective of most studies was to evaluate lymphatic and hematopoietic malignancies, including leukemia, myeloma, HD and NHL. NHL was mostly classified as a whole 
disease which included all sub-types. Three studies differentiated reticulum cell sarcomas and Iymphosarcomas, one study classified it according to the severity of the disease as low or high grade. Two studies made the distinction between low and high grades, and/ or differentiated between diffuse and follicular patterns of the tumor. In comparing studies where pathologists reviewed slides with studies having no slide review, there was no difference between the results. This issue was the target point of a review of 668 slides of $\mathrm{NHL}$, and an agreement of $93 \%$ was observed between reported diagnosis and the panel review. It was concluded that depending on the degree of potential bias allowable in the study being undertaken, panel review to confirm diagnoses of NHL may not be necessary and panel review to develop subtypes of NHL may not be useful in epidemiologic studies, especially relative to the time and cost involved (Dick et al., 1987). As mentioned, most studies did not use the current classification systems to differentiate various histologies of NHL. One reason for not using a detailed classification scheme may be the size of the study that would be required to have a sufficient number of cases or even a few of the various histologies that would achieve statistical significance for a twofold relative risk or less (Scherr \& Mueller, 1996).

Twenty seven $(60.0 \%)$ studies had information about exposure to specific agents, but only five (11.1\%) were based on environmental measurements. Most studies used job titles (62.2\%) and/or industries (46.6\%) as the measure of the exposure. Twenty two studies (48.9\%) got information from questionnaires and five (11.1\%) used chemistry or industrial hygiene expert judgments to complete the available information. This latter procedure has been generally recognized as the reference method for exposure evaluation, at least for population-based case-control studies (Bouyer \& Hémon, 1993; Stücker et al., 1993).

In 34 studies of a total of 41 (82.9\%), 68 non-statistically significant associations were found. Two studies published only statistically significant associations. No associations were seen in 29 of 39 studies (74.3\%) which referred to negative results. It is impossible to enumerate all of them, because some of these associations were not pointed out by the authors.

Fifty four statistically significant associations between solvent exposure or related occupations or industries were reported in 25 studies (55.5\%). For each study, these associations were seen: (1) lymphosarcoma and proximity with chemical industry; (2) benzene and related occupations; (3) printing; (4) styrene, trichloroethylene, perchloroethylene, benzene, other solvents and solvents plus chlorophenols and phenoxi acids; (5) solvents (female); (6) wood industry; (7) lacquers and varnish, engine exhaust, hydrocarbon coats and cleaners, paint aerosols and gasoline as a cleaning agent; (8) glues; (9) rubber, plastics and synthetics; (10) solvents; (11) ethanol unit, foremen and instrument men; (12) solvents and carpenters; (13) mineral oil; (14) car per household and car per thousands; (15) carpenters and other simiIar; (16) carpenters; (17) high exposure to solvents and diffuse NHL; (18) shoe workers, porcelain workers, furniture workers and lorry drivers; (19) organic solvents; (20) chemical workers less than 65 years; (21) styrene less than 10 years of exposure with $1-49 \%$ of workers in production section; (22) mechanics, electronic and electrical repairs and ship building; (23) mixture of benzene, toluene and xylene and inks; (24) benzene; (25) solvents and small cell diffuse.

In a review of the epidemiology of the occupational factors of chemically induced lymphoid and hemopoietic cancers, the difficulties associated with such a review are recognized. They are mainly related to both disease and exposure definitions. However, consistent findings were reported for occupations with benzene exposure (Tsongas, 1985). Another review about leukemia and lymphoma risks derived from solvents pointed out that a relation between solvent exposure and malignant lymphomas has been called into question (Brandt, 1987). The author referred the contradictory results from specific studies and mentioned that the reasons are obscure. It was explained that, apparently, the studies which failed to find an association were based on register data or occupational titles, suggesting the need for further investigations in this field.

Some occupations were shown to be related with NHL as in the cases of the rubber industry (Monson \& Nakano, 1976; Wilcosky et al., 1984; Delzel \& Monson, 1984); petroleum refining workers (Thomas et al., 1982; Wen et al., 1983; Delzell et al., 1988); chemists (Li et al., 1969; Searle et al., 1978; Olin, 1978; Olin \& Ahlbom, 1980; Rinsky et al., 1988); printers (Zoloth et al., 1986); highway workers (Maizlish et al., 1988); dry cleaners (Blair et al., 1990) and heavy machinery production workers (Mallin et al., 1986). The etiologic agents responsible for these excess have not been identified definitively, but all occupations have exposure to organic solvents in common (Zahm, 1996). 
Beyond the millions of industrial workers with potential exposure to solvents, the general population is also potentially exposed through contact with commercial products and contaminated drinking water. Because exposures have increased over the same time period as the increase in $\mathrm{NHL}$, it is plausible that solvents may have contributed to rising incidence (Ries et al.,1994). Besides, a low risk was observed for all lympho-hematopoietic cancers, including NHL in Circumpolar Inuit, which suggested that it may reflect protective environment or genetic factors (Lanier \& Alberts, 1996).
Twenty three studies (51.1\%) concluded either that there was no association, or that there was no need for future investigations, even if there was the possibility of relationship. Some studies suggested that organic solvents can act as a risk factor for NHL development. It was noticed in this review that statistical significance was more frequently shown in studies where solvent exposure was more accurately defined, OR =5.2 (1.11-26.19) - exposure to organics solvents was specifically evaluated: yes/ no; results with statisti cally significance: yes/ no. Eighteen such studies, 13 (72.2\%) defined or suggested organic solvents as possible risk factors for NHL.

Table1

Studies on non-Hodgkin's lymphoma in relation to potential occupational organic solvents exposure.

\begin{tabular}{|c|c|c|c|c|c|}
\hline $\begin{array}{l}\text { Authors/year/ } \\
\text { country }\end{array}$ & Design & Source population & $\begin{array}{l}\text { Study } \\
\text { Subjects }\end{array}$ & $\begin{array}{l}\text { Disease } \\
\text { Classification }\end{array}$ & Exposure \\
\hline
\end{tabular}

1- Capurro, 1979, Clinical A community of Caucasian 117 individuals Lymphoma

USA case series people from 1968 to 1974

\section{Solvent exposure}

measured in the environment and in the blood of the residents
23 cases of cancer, 8 of them were lymphoma; considering specifically

the 3 deaths due to lymphosarcoma in a 6 year period, $\mathrm{O} / \mathrm{Ei}=3 / 0.0187=$ 160 fold

\begin{tabular}{lll}
\hline $\begin{array}{l}\text { 2- Vianna \& Polan, } \\
\text { 1979, USA }\end{array}$ & $\begin{array}{l}\text { Cohort } \\
\text { mortality }\end{array}$ & All deaths male $\geq$ age 20 \\
& with RCS, LS or HDii from \\
& death certificates of N ew \\
& York State, excluding N ew \\
& York City, from 1950 to 1969
\end{tabular}

$\begin{array}{llll}146 \text { RCS; } 353 & \text { RCS; LS } & \text { Benzene }- & \text { RCS: RRiii }=1.6 ; \\ \text { LS and 267 HD and HD } & \text { related occupations } & \text { LS: RR }=2.1 ; \\ & & \text { HD: RR }=1.6 \\ & & \text { For } 45 \text { years old and over: } \\ & \text { RCS: } 0 / E=1.7 p<0.01 \\ & & \text { LS: } O / E=2.1 p<0.01 \\ & \text { HD: } 0 / E=1.9 p<0.01\end{array}$

3,056 counties ICDiv 200, Proportion of printing 202 and 205 chemical, petroleum furniture, electrical, machinery and rubber industries per each county rates for $\mathrm{NHLii}$ in countie of the contiguous U.S.
Associations in a multiple regression analysis for white males and printing ( $\beta$ significant at $p<0.025$ ), petrochemicals and rubber products

\begin{tabular}{|c|c|c|c|c|c|c|}
\hline $\begin{array}{l}\text { 4- Hardell et al., } \\
\text { 1981, Sweden }\end{array}$ & $\begin{array}{l}\text { Hospital- } \\
\text { based case- } \\
\text { control }\end{array}$ & $\begin{array}{l}\text { Cases: all men assisted in } \\
\text { the Dep. O f O ncology in } \\
\text { Umea (catchment area), } \\
25-85 \text { years old; controls: } \\
8 \text { matched (age, sex, } \\
\text { residence) controls for each } \\
\text { living case and } 10 \text { matched } \\
\text { (age, sex, residence and year } \\
\text { of death) from the National } \\
\text { Population Registry }\end{array}$ & $\begin{array}{l}\text { Cases: } 109 \\
\text { NHL and } \\
60 \mathrm{HD} \text {; } \\
\text { controls: } 338 \\
\text { ar }\end{array}$ & $\begin{array}{l}\text { Lukes-Collins } \\
\text { (modified) }\end{array}$ & $\begin{array}{l}\text { Self administered } \\
\text { questionnaires, } \\
\text { supplemented by } \\
\text { telephone; high and low } \\
\text { grade solvent exposure }\end{array}$ & $\begin{array}{l}\text { low grade: } \mathrm{RR}=1.2 \\
(0.5-2.6) ; \text { high grade } \\
\text { (Styrene, trichloroethylene, } \\
\text { perchloroethylene, } \\
\text { benzene): RR }=4.6 \\
(1.9-11.4) \text {, other: } \mathrm{RR}=2.8 \\
(1.6-4.8) ; \text { high + low: } \\
\text { RR }=2.4(1.5-3.8) ; \\
\text { solvents + chlorophenols } \\
\text { and phenoxy acids: } \\
\text { RR }=8.5(4.4-17.2)\end{array}$ \\
\hline $\begin{array}{l}\text { 5- Meinhardt et al., } \\
\text { 1982, USA }\end{array}$ & $\begin{array}{l}\text { Cohort } \\
\text { mortality }\end{array}$ & $\begin{array}{l}\text { Workers in } 2 \text { styrene- } \\
\text { butadiene rubber plants }\end{array}$ & $\begin{array}{l}\text { Plant A: } \\
1662 \text { indiv. } \\
34,187 \mathrm{p} / \mathrm{y} \\
\text { Plant B: } \\
1094 \text { indiv. } \\
19,742 \mathrm{p} / \mathrm{y}\end{array}$ & $\begin{array}{l}\text { Hematopoi- } \\
\text { etic and } \\
\text { lymphatic } \\
\text { malignancies } \\
\text { ICD: 200-205 }\end{array}$ & $\begin{array}{l}\text { Butadiene, styrene } \\
\text { and benzene } \\
\text { environmental } \\
\text { measures }\end{array}$ & $\begin{array}{l}\text { Lymphatic and } \\
\text { hematopoietic tissues } \\
(220-205): \text { SM Riii }=155 \\
\text { (plant } A) \text { and } 78 \text { (plant } B \text { ); } \\
\text { lympho and reticulosar- } \\
\text { coma (200): SM R= } 181 \\
\text { (plant } A) \text { and } 132 \text { (plantB). } \\
\text { Excess mortality not } \\
\text { statistically significant }\end{array}$ \\
\hline
\end{tabular}


Table1 (cont.)

\begin{tabular}{|c|c|c|c|c|c|}
\hline $\begin{array}{l}\text { Authors/year/ } \\
\text { country }\end{array}$ & Design & Source population & $\begin{array}{l}\text { Study } \\
\text { Subjects }\end{array}$ & $\begin{array}{l}\text { Disease } \\
\text { Classification }\end{array}$ & Exposure \\
\hline $\begin{array}{l}\text { 6- Balarajan, } \\
\text { 1983, UK }\end{array}$ & $\begin{array}{l}\text { Registry- } \\
\text { based case } \\
\text { control }\end{array}$ & $\begin{array}{l}\text { Cases: malignant } \\
\text { lymphomas in men } \\
\text { aged } 15 \text { and over, from } \\
1973 \text { to } 1977 \text { collected } \\
\text { at the N ational Cancer } \\
\text { Registry; controls: randomly } \\
\text { chosen from other cancers, } \\
\text { matched } 1: 1 \text { by age, sex and } \\
\text { region of residence }\end{array}$ & $\begin{array}{l}\text { Cases: } 426 \\
\text { lymphomas } \\
\text { ( } 256 \text { N HL); } \\
\text { controls: } 256\end{array}$ & $\begin{array}{l}\text { ICD 8th : } \\
200 \text { and } \\
202\end{array}$ & Road transport workers \\
\hline
\end{tabular}

Results

ICD 200: drivers of buses

and coaches: $O R$ iii $=1.16$

(0.60-2.26); drivers of other road passenger vehicles:

$\mathrm{OR}=0.95$ (0.48-1.88);

drivers of road goods vehicles: $O R=0.93(0.71$

1.22); bus conductors:

$\mathrm{OR}=0.57(0.12-2.25)$

lorry drivers' mates, etc.: no cases; ICD 202: drivers of buses and coaches: $\mathrm{O} R=1.63(0.62-4.52)$ drivers of other road passenger vehicles: $\mathrm{OR}=$ 1.67 (0.68-4.32); drivers of road goods vehicles: $O R=$ 0.90 (0.63-1.28); bus conductors: $\mathrm{OR}=2.67$ (0.64-15.6); lorry drivers' mates, etc.: no cases

\begin{tabular}{|c|c|c|c|c|c|c|}
\hline $\begin{array}{l}\text { 7- Franco \& } \\
\text { Ponte, } 1983, \\
\text { Italy }\end{array}$ & $\begin{array}{l}\text { Hospital- } \\
\text { based } \\
\text { case-control }\end{array}$ & $\begin{array}{l}\text { Cases: patients of both } \\
\text { sexes admitted to the } \\
\text { Clinica M edica A. Ferrata - } \\
\text { University of Pavia, from } \\
1969 \text { to } 1980 \text {, diagnosed } \\
\text { as malignant lymphoma; } \\
\text { controls: patients } \\
\text { admitted to an internal } \\
\text { medicine unit in Pavia } \\
\text { from } 1975 \text { to } 1980\end{array}$ & $\begin{array}{l}\text { Cases: } 282 \\
\text { N HL and } 387 \\
\text { HD ( } 347 \text { male } \\
\text { and } 322 \\
\text { female; } \\
\text { controls: } 757 \\
\text { male and } 588 \\
\text { female }\end{array}$ & NHL & $\begin{array}{l}\text { Occupations as proposed } \\
\text { by the Annuario } \\
\text { Statistico Italiano }\end{array}$ & $\begin{array}{l}\text { Chemical and } \\
\text { pharmaceutical: } 4 \text { ECiii, } \\
O R=0.16 \text {; Textiles, shoes } \\
\text { and leather: } 21 \mathrm{EC} \text {, } \\
\mathrm{OR}=0.50 ; \text { Paper and } \\
\text { printing: } 3 \mathrm{EC}, \mathrm{OR}=0.90 ; \\
\text { rubber and plastics: } 3 \mathrm{EC}, \\
\mathrm{OR}=0.33 \text {; wood: } 14 \mathrm{EC} \text {, } \\
\mathrm{OR}=5.55(2.39-12.85)\end{array}$ \\
\hline $\begin{array}{l}\text { 8- Bernard et al., } \\
1984, \text { UK }\end{array}$ & $\begin{array}{l}\text { Hospital- } \\
\text { based } \\
\text { case-control }\end{array}$ & $\begin{array}{l}\text { Cases: all new cases } \\
\text { diagnosed between } \\
\text { O ctober/1979 and } \\
\text { December/1981 in adult } \\
\text { residents in six health } \\
\text { districts in Yorkshire } \\
\text { Health Region; controls: } \\
1: 1 \text { hospital patients, } \\
\text { matched for age, sex and } \\
\text { geographic area }\end{array}$ & $\begin{array}{l}\text { Cases: } 81 \text { male } \\
\text { and } 77 \text { female } \\
\text { NHL; } 48 \mathrm{HD} ; \\
66 \text { CLLii; } 13 \mathrm{ALL} \\
\text { controls: } 162 \text { mal } \\
\text { and } 154 \text { female } \\
\text { patients for N HL } \\
\text { cases }\end{array}$ & $\begin{array}{l}\mathrm{NHL} \\
\text { ale } \\
\mathrm{L}\end{array}$ & $\begin{array}{l}\text { Questionnaires applied } \\
\text { by one interviewer; } \\
\text { past occupations } \\
\text { and selected exposures }\end{array}$ & $\begin{array}{l}\text { O ccupational solvents } \\
\text { (excluding benzene): } \\
\text { OR = } 1.52(0.70-3.26) \\
\text { male; } O R=7.71(1.24- \\
47.93) \text { female; petroleum } \\
\text { industries: } O R=4.21 \\
(0.54-32.79) \text { male; } \\
\text { solvent use as hobby: } \\
O R=1.39(0.30-6.46) \\
\text { male; benzene: } O R=0.49 \\
(0.21-2.0) \text { male; petrol } \\
\text { products: } O R=0.59(0.25- \\
1.39) \text { both sex; hair } \\
\text { sprays: OR }=1.49(0.75- \\
2.95) \text { female; hair sprays: } \\
\text { OR }=4.67(1.50-13.63) \\
\text { female }>65 \text { years old }\end{array}$ \\
\hline $\begin{array}{l}\text { 9- Giles et al., } \\
\text { 1984, Australia }\end{array}$ & $\begin{array}{l}\text { Population- } \\
\text { based case- } \\
\text { control }\end{array}$ & $\begin{array}{l}\text { Cases: all incident } \\
\text { cases of } \\
\text { myeloproliferative } \\
\text { and lymphoproliferative } \\
\text { diseases in Tasmania } \\
\text { from } 1972 \text { to 1980; } \\
\text { controls: } 1: 1 \text { age and } \\
\text { sex matched from } \\
\text { electoral rolls and Child } \\
\text { and School Health Services }\end{array}$ & $\begin{array}{l}\text { Cases: } 798 \\
\text { total cases, } \\
241 \text { NHL (125 } \\
\text { male and } 116 \\
\text { female); } \\
\text { controls: } 241\end{array}$ & $\begin{array}{l}\text { All cases } \\
\text { reviewed by } \\
\text { an oncologist, } \\
\text { a hematologist } \\
\text { and a patholog }\end{array}$ & $\begin{array}{l}\text { Personal interview; } \\
\text { occupations } \\
\text { t } \\
\text { gist }\end{array}$ & $\begin{array}{l}\text { Male foundry workers: } \\
\text { OR = } 8.0(1.07-356.0) \\
\text { female hairdressers: } \\
5 \text { exposed cases and no } \\
\text { exposed controls }\end{array}$ \\
\hline
\end{tabular}


Table1 (cont.)

\begin{tabular}{lll}
\hline $\begin{array}{l}\text { Authors/year/ } \\
\text { country }\end{array}$ & Design & Source population \\
\hline $\begin{array}{ll}\text { 10- Everett et al., } \\
1985, \text { USA }\end{array}$ & $\begin{array}{ll}\text { Population- } \\
\text { based case- } \\
\text { control }\end{array}$ & $\begin{array}{l}\text { Cases: men with NHL } \\
\text { and leukemia; controls: } \\
\text { selected by random } \\
\text { dialing and from social } \\
\text { security files }\end{array}$
\end{tabular}

$\begin{array}{lll}\text { Study } & \text { Disease Exposure } & \text { Results }\end{array}$

Subjects Classification

Cases: $1200 \mathrm{NHL} \quad$ Personal interview; Lacquers/varnishes:

controls: not

exposure evaluation

$O R=1.24 p<0.1$;

cited

to a series of chemicals

engine exhaust:

security files

in the workplace or home

hydrocarbon coats:

$O R=1.67 p<0.1$;

hydrocarbon cleaners:

$O R=2.13 p<0.001$

paint aerosols: $O R=1.28$

$p<0.1$; gasoline as a

cleaning agent: $O R=1.29$

$\mathrm{p}<0.05$

\begin{tabular}{|c|c|c|c|c|c|c|}
\hline $\begin{array}{l}\text { 11- Binaschi et al., } \\
\text { 1985, Italy }\end{array}$ & $\begin{array}{l}\text { Hospital- } \\
\text { based case- } \\
\text { control }\end{array}$ & $\begin{array}{l}\text { Cases: patients ad mitted } \\
\text { to the Hospital of Varese } \\
\text { to treat NHL and HD } \\
\text { during } 1984 \text {, living in that } \\
\text { city for at least } 15 \text { years; } \\
\text { controls: patients admitted } \\
\text { to the same hospital to treat } \\
\text { other non-cancer diseases }\end{array}$ & $\begin{array}{l}\text { Cases: } 43 \mathrm{NHL} \\
\text { (14 male and } \\
28 \text { female) and } \\
46 \mathrm{HD} ; \\
\text { controls: } 89 \\
t\end{array}$ & NHL (Kiel) & $\begin{array}{l}\text { Personal interview; } \\
\text { occupations }\end{array}$ & $\begin{array}{l}\text { M etal-mechanics: } \\
\text { RR }=1.98(0.75-5.20) \\
13 \mathrm{EC} \text {; chemists: } \mathrm{RR}=1.0 \\
(0.27-3.74) 4 \mathrm{EC}\end{array}$ \\
\hline
\end{tabular}

\begin{tabular}{|c|c|c|c|c|c|}
\hline $\begin{array}{l}\text { 12- Schumacher \& } \\
\text { Delzell, } 1988, \text { USA }\end{array}$ & $\begin{array}{l}\text { Death } \\
\text { certificate- } \\
\text { based case- } \\
\text { control }\end{array}$ & $\begin{array}{l}\text { Cases: men who died from } \\
\text { age } 35 \text { to } 75, \text { between } \\
\text { 1968-1970; 1975- } 1977 ; \\
\text { 1980-1982; controls: other } \\
\text { non-cancer deaths, } \\
\text { frequency matched by age, } \\
\text { year of death and race, 1:1 } \\
\text { whites and } 2: 1 \text { blacks }\end{array}$ & $\begin{array}{l}\text { Cases: } 501 \quad \text { ICD 200-202 } \\
\text { controls: } 569\end{array}$ & Occupations & $\begin{array}{l}\text { Benzene: whites OR }=0.77 \\
(0.56-1.07) ; \text { blacks } \\
\text { OR }=0.94(0.47-1.87) \\
\text { chemicals, drugs and } \\
\text { paints: whites OR }=0.67 \\
(0.3-1.51) ; \text { blacks } 1 \\
\text { exposed case, no exposed } \\
\text { control (0.21- ) rubber, } \\
\text { plastics and synthetics: } \\
\text { whites } 4 \text { exposed cases, } \\
\text { no exposed controls } \\
\text { (1.29-) fuel: whites } \\
\text { OR }=0.97 \text { (0.19-5.02) } \\
\text { blacks no cases and no } \\
\text { controls furniture: whites } \\
\text { OR }=0.74(0.43-1.26)\end{array}$ \\
\hline
\end{tabular}

\begin{tabular}{|c|c|c|c|c|c|c|}
\hline $\begin{array}{l}\text { 13- Brownson \& } \\
\text { Reif, 1988, USA }\end{array}$ & $\begin{array}{l}\text { Cancer } \\
\text { registry- } \\
\text { based case- } \\
\text { control }\end{array}$ & $\begin{array}{l}\text { Cases: males, age } 20 \text { and } \\
\text { over from M issouri Cancer } \\
\text { Registry (1984-1985); } \\
\text { controls: } 3 \text { age matched } \\
\text { white males to each case } \\
\text { from the same source } \\
\text { excluding smoke-related } \\
\text { cancers and prostate cancer }\end{array}$ & $\begin{array}{l}\text { Cases: } 222 \\
\text { controls: } 666 \\
\end{array}$ & ICD 200-202 & $\begin{array}{l}\text { Usual occupation and } \\
\text { industries collected by } \\
\text { Missouri Center Registry }\end{array}$ & $\begin{array}{l}\text { Printers: } \mathrm{OR}=2.72 \\
(0.96-7.69) ; \text { no } \\
\text { associations were found } \\
\text { with other solvent-related } \\
\text { occupations }\end{array}$ \\
\hline $\begin{array}{l}\text { 14- Olsson \& } \\
\text { Brandt, 1988, } \\
\text { Sweden }\end{array}$ & $\begin{array}{l}\text { Hospital- } \\
\text { based case- } \\
\text { control }\end{array}$ & $\begin{array}{l}\text { Cases: a consecutive } \\
\text { series of men admitted } \\
\text { in 1978-1981, in the } \\
\text { Department of O ncology, } \\
\text { University Hospital, Lund; } \\
\text { controls: two groups of } \\
\text { healthy men selected from } \\
\text { population registry }\end{array}$ & $\begin{array}{l}\text { Cases: } 167 \\
\text { controls: } 130\end{array}$ & Rappaport & $\begin{array}{l}\text { Q uestionnaires ap plied } \\
\text { by interviewers; } \\
\text { Exposure: handling } \\
\text { organic solvents for at } \\
\text { least one year daily }\end{array}$ & $\begin{array}{l}\text { Categorization in five year } \\
\text { age group: } O \mathrm{R}_{\mathrm{M}-\mathrm{H}}=3.3 \\
\text { (1.9-5.8); supra- } \\
\text { diaphrag matic tumo rs: } \\
\mathrm{OR}=6.5(3.2-13.3) \text {; } \\
\text { other tumor presentations: } \\
\mathrm{OR}=2.3(1.3-4.3)\end{array}$ \\
\hline $\begin{array}{l}\text { 15- Dubrow et al., } \\
1988, \text { USA }\end{array}$ & $\begin{array}{l}\text { Death } \\
\text { certificate- } \\
\text { based case- } \\
\text { control }\end{array}$ & $\begin{array}{l}\text { Cases: all white male } \\
\text { residents of Hancock } \\
\text { County, aged } 15 \text { or } \\
\text { more, died during 1958- } \\
\text { 83; controls: } 4: 1 \text { chosen } \\
\text { as a stratified random } \\
\text { sample by age at death } \\
\text { and year of death }\end{array}$ & $\begin{array}{l}\text { Cases: } 61 \mathrm{NHL} \\
\text { and } 15 \mathrm{HD} ; \\
\text { controls: } 304\end{array}$ & $\begin{array}{l}\text { ICD } 7^{\text {th }}(200, \\
202 \text { and } \\
205), 8^{\text {th }} \\
(200 \text { and } \\
202) \text { and } 9 \text { th } \\
(200 \text { and } \\
202 \text { except } \\
202.2 \text { and } \\
202.6)\end{array}$ & $\begin{array}{l}\text { Occupation and usual } \\
\text { industry or business }\end{array}$ & $\begin{array}{l}\text { No asso ciations were } \\
\text { found with solvent- } \\
\text { related occupations or } \\
\text { industries }\end{array}$ \\
\hline
\end{tabular}


Table1 (cont.)

\begin{tabular}{|c|c|c|c|c|c|c|}
\hline $\begin{array}{l}\text { Authors/year/ } \\
\text { country }\end{array}$ & Design & Source population & $\begin{array}{l}\text { Study } \\
\text { Subjects }\end{array}$ & $\begin{array}{l}\text { Disease } \\
\text { Classification }\end{array}$ & Exposure & Results \\
\hline $\begin{array}{l}\text { 16- Cartwright et al., } \\
\text { 1988, UK }\end{array}$ & $\begin{array}{l}\text { Hospital- } \\
\text { based case- } \\
\text { control }\end{array}$ & $\begin{array}{l}\text { Cases: all new cases } \\
\text { diagnosed between } \\
1979 \text { and } 1984 \text { in adult } \\
\text { residents in all districts } \\
\text { in Yorkshire Health Region; } \\
\text { controls: } 2: 1 \text { non-cancer } \\
\text { hospital inpatients, matched } \\
\text { for age, sex and residential } \\
\text { health district }\end{array}$ & $\begin{array}{l}\text { Cases: } 437 \\
\text { ( } 244 \text { males } \\
\text { and } 193 \\
\text { females); } \\
\text { controls: } 724\end{array}$ & $\begin{array}{l}\mathrm{NHL} \\
\text { confirmed by } \\
\text { the Regional } \\
\text { Histopathol- } \\
\text { ogy Lym- } \\
\text { phoma Panel }\end{array}$ & $\begin{array}{l}\text { Questionnaires applied } \\
\text { by interviewers; past } \\
\text { occupations and selected } \\
\text { exposures }\end{array}$ & $\begin{array}{l}\text { Solvents: OR }=1.2 \\
(0.9-1.5) ; \text { glues: } O R=1.8 \\
(1.2-2.6) ; \text { other non- } \\
\text { significant associations } \\
\text { without referring OR } \\
\text { value: chemical workers; } \\
\text { printers; painters and } \\
\text { decorators }\end{array}$ \\
\hline $\begin{array}{l}\text { 17- Garland et al., } \\
1988, \text { USA }\end{array}$ & Cohort & $\begin{array}{l}\text { Exposed group: all white } \\
\text { U.S. N avy enlisted men } \\
\text { during 1974-1983; } \\
\text { unexposed group: U.S. } \\
\text { population provided by } \\
\text { SEERv }\end{array}$ & $\begin{array}{l}\text { Exposed } \\
\text { group: } \\
\text { 435,425 men/ } \\
3,704,864 \\
\text { person/years; }\end{array}$ & $\begin{array}{l}\text { NHL } \\
\text { reviewed } \\
\text { by a board } \\
\text { of specialists } \\
\text { ICD } 8 \text { th }(200.0 \text {, } \\
200.1,202.0- \\
202.9) \text {; ICD } 9 \text { th: } \\
200.0,200.1 \\
202.1,202.8 \\
202.9\end{array}$ & $\begin{array}{l}80 \text { U.S. Navy } \\
\text { occupations } \\
\text { h: }\end{array}$ & $\begin{array}{l}68 \mathrm{NHL} \text { cases in the } \\
\text { exposed group; aviation } \\
\text { structural mechanic: } \\
5 \text { cases, SIR }=1.5(0.5-3.5) \text {; } \\
\text { machinery repairman: } \\
1 \text { case, SIR = } 1.8(0.0-10.0) ;\end{array}$ \\
\hline $\begin{array}{l}\text { 18- Ott et al., 1989, } \\
\text { USA }\end{array}$ & $\begin{array}{l}\text { Nested } \\
\text { case- } \\
\text { control }\end{array}$ & $\begin{array}{l}\text { Cases: selected from a } \\
\text { cohort of } 29,139 \text { men in } \\
\text { two chemical plants; } \\
\text { controls: selected from the } \\
\text { total employee cohort } \\
\text { according to a group- } \\
\text { matched incidence density } \\
\text { sampling in a } 5: 1 \text { ratio }\end{array}$ & $\begin{array}{l}\text { Cases: 52; } \\
\text { controls: } 260\end{array}$ & $\mathrm{NHL}$ & $\begin{array}{l}111 \text { work areas, } \\
52 \text { chemical activity } \\
\text { groups and } 21 \\
\text { specific chemicals }\end{array}$ & $\begin{array}{l}\text { Ethanol unit OR }=5.4 \\
(1.5-19.5) ; \text { foremen and } \\
\text { others O } R=3.2(1.4-7.2) \text {; } \\
\text { instrument men O }=5.2 \\
(1-26.7)\end{array}$ \\
\hline $\begin{array}{l}\text { 19- Franceschi et al., } \\
1989, \text { Italy }\end{array}$ & $\begin{array}{l}\text { Hospital- } \\
\text { based case- } \\
\text { control }\end{array}$ & $\begin{array}{l}\text { Cases: men and women } \\
\text { below age 80, admitted } \\
\text { from J une } 1983 \text { to March } \\
1988 \text { at Aviano Cancer } \\
\text { Center and all general } \\
\text { hospitals in province of } \\
\text { Pordenone; controls: men } \\
\text { and women age } 17-79 \text { with } \\
\text { acute disorders, from the sam } \\
\text { hospitals and catchment area }\end{array}$ & $\begin{array}{l}\text { Cases: } 208 \\
\text { (110 males and } \\
98 \text { females); } \\
\text { controls: } 401 \\
\text { ( } 215 \text { males and } \\
186 \text { females) } \\
\text { me } \\
\text { a }\end{array}$ & $\begin{array}{l}\text { ICD 200-202; } \\
\text { Rappaport; } \\
\text { International } \\
\text { Working } \\
\text { Formulation }\end{array}$ & $\begin{array}{l}\text { Q uestionnaires applied } \\
\text { by interviewers; } 20 \\
\text { potentially carcinogenic } \\
\text { chemical or physical } \\
\text { agents }\end{array}$ & $\begin{array}{l}\text { Chemical workers: } \\
O R=1.64(0.88-3.06) \\
\text { petrochemical: } O R=1.83 \\
\text { (0.87-3.84) } \\
\text { dye and paint: } O R=0.72 \\
(0.36-1.44) \\
\text { plastic resin/glue: } \\
O R=1.01(0.46-2.23) \\
\text { benzene/solvents: } \\
O R=1.14 \text { (0.57-2.28) } \\
\text { wood/furniture: } O R=0.66 \\
(0.37-1.19)\end{array}$ \\
\hline $\begin{array}{l}\text { 20- La Vecchia et al., } \\
\text { 1989, Italy }\end{array}$ & $\begin{array}{l}\text { Hospital- } \\
\text { based case- } \\
\text { control }\end{array}$ & $\begin{array}{l}\text { Cases: patients aged } \\
\text { 15-74, admitted in to a } \\
\text { network of teaching and } \\
\text { general hospitals in the } \\
\text { greater Milan area, from } \\
\text { J une } 1983 \text { to O cto ber } \\
\text { 1988; controls: patients } \\
\text { admitted in the same } \\
\text { hospitals with acute } \\
\text { conditions }\end{array}$ & $\begin{array}{l}\text { Cases: } 153 \\
\mathrm{NHL}(93 \\
\text { males and } 60 \\
\text { females); } \\
69 \mathrm{HD} \text { and } \\
110 \text { multiple } \\
\text { myeloma; } \\
\text { controls: } 396 \\
\text { (269 males and } \\
127 \text { females) }\end{array}$ & $\begin{array}{l}\mathrm{NHL} \\
\text { histologically } \\
\text { confirmed }\end{array}$ & $\begin{array}{l}\text { Q uestionnaires applied } \\
\text { by interviewers; } \\
\text { Exposure: } 16 \text { industries } \\
\text { or occupations and } \\
13 \text { selected occupational } \\
\text { agents or group of ag ents }\end{array}$ & $\begin{array}{l}\text { No associations were } \\
\text { found between N HL and } \\
\text { solvent-related occupations } \\
\text { (chemical, petrochemical } \\
\text { plastic resins/glues, } \\
\text { solvents/benzene, oil, } \\
\text { dyes/paints, rubber, } \\
\text { printing and furniture) }\end{array}$ \\
\hline $\begin{array}{l}\text { 21- Persson et al., } \\
\text { 1989, Sweden }\end{array}$ & $\begin{array}{l}\text { Hospital- } \\
\text { based case- } \\
\text { control }\end{array}$ & $\begin{array}{l}\text { Cases: NHL and HD } \\
\text { obtained from the } \\
\text { Department of } \\
\text { Oncology at Ö rebo } \\
\text { Medical Centre Hospital, } \\
\text { diagnosed between } 1964 \\
\text { and } 1986, \text { alive in } 1986, \\
\text { aged 20-80; controls: from } \\
\text { the population registry, } \\
\text { resident in the same } \\
\text { catchment area of the cases }\end{array}$ & $\begin{array}{l}\text { Cases: } 106 \\
\text { N HL ( } 66 \text { men } \\
\text { and } 40 \text { women) } \\
\text { and } 54 \text { HD; } \\
\text { controls: } 275\end{array}$ & $\mathrm{NHL}$ & $\begin{array}{l}\text { Posted questionnaires; } \\
\text { Five levels of solvent } \\
\text { exposure, at least for } \\
1 \text { year }\end{array}$ & $\begin{array}{l}\text { Solvents: OR }=2.0(33 / 50 \\
\text { exposed cases/controls); } \\
\text { thinner OR }=2.7(15 / 16) ; \\
\text { white spirit: OR }=3.1 \\
\text { (13/12); trichloroethylene: } \\
O R=1.5(8 / 14) ; \text { styrene: } \\
O R=8.0(3 / 1) \text {; painters: } \\
O R=\infty(3 / 0) ; \text { plastic/rubber } \\
\text { chemicals: OR = 2.5 }(9 / 10) ; \\
\text { carpenter/cabinet makers: } \\
O R=3.1(10 / 9)\end{array}$ \\
\hline
\end{tabular}


Table1 (cont.)

\begin{tabular}{|c|c|c|c|c|c|c|}
\hline $\begin{array}{l}\text { Authors/year/ } \\
\text { country }\end{array}$ & Design & Source population & $\begin{array}{l}\text { Study } \\
\text { Subjects }\end{array}$ & $\begin{array}{l}\text { Disease } \\
\text { Classification }\end{array}$ & Exposure & Results \\
\hline $\begin{array}{l}\text { 22- Weisenburger } \\
\text { et al., 1990, USA }\end{array}$ & $\begin{array}{l}\text { Population- } \\
\text { based case- } \\
\text { control }\end{array}$ & $\begin{array}{l}\text { Cases: N HL in men aged } \\
21 \text { or older in } 66 \text { counties } \\
\text { of eastern N ebraska, from } \\
198 \text { to } 1986 \text {, identified } \\
\text { through the Nebraska } \\
\text { Lymphoma Study Group } \\
\text { Registry and area hospitals } \\
\text { and physicians; controls: } \\
\text { selected from residents of the } \\
\text { same area, matched by age, } \\
\text { race and vital status }\end{array}$ & $\begin{array}{l}\text { Cases: } 201 ; \\
\text { controls: } 725\end{array}$ & $\begin{array}{l}\text { cases } \\
\text { reviewed by } \\
\text { pathologist }\end{array}$ & $\begin{array}{l}\text { Telephone interviews; } \\
\text { specific ag ents in farm } \\
\text { practices }\end{array}$ & $\begin{array}{l}\text { Chlorinated hydrocarbons: } \\
\text { OR }=1.9(0.8-2.3)\end{array}$ \\
\hline
\end{tabular}

\begin{tabular}{ll}
\hline 23- Pasqualetti & Hospital- \\
et al., 1991, Italy & based case- \\
& control
\end{tabular}

Cases: hospital patients

Cases: 108

NHL within

620 total

hematological

malignancies; controls:

sex and age matched

hospital controls with

"medical diseases", from

the same area as the cases neoplasms;

controls: 216

within 1,240

total
NHL

Q uestionnaires applied

by interviewers in $59 \%$ of

the cases and $85 \%$ of the

controls; remaining

information obtained

from relatives

categories
Exposure: 21 risk

Hematological

malignancies: industrial

activities $\mathrm{OR}=2.97$

(1.98-4.46); exposure to aromatic hydrocarbons $\mathrm{OR}=2.15$ (1.39-3.32).

dyes and inks $O R=1.28$

(1.11-1.99); mineral oils $\mathrm{OR}=2.59$ (1.75-3.84);

paints and related products $O R=1.55$ (1.06-2.26). N HL: mineral oils OR $=3.4$ (1.65-7.38).

No association between

$\mathrm{NHL}$ and auto-mechanics, railroad workers, and specific exposures to cetonas, aliphatic hydrocarbons, chlorinated hydrocarbons, and dye, paints and inks

\begin{tabular}{|c|c|c|c|c|c|c|}
\hline $\begin{array}{l}\text { 24- Skov \& Lynge, } \\
\text { 1991, Denmark }\end{array}$ & Cohort & $\begin{array}{l}\text { Persons aged 20-64 in } \\
1970 \text { (census data on } \\
\text { industry and occupations) } \\
\text { followed up for cancer } \\
\text { incidence until } 1980 \\
\text { linked with Danish Cancer } \\
\text { Registry data }\end{array}$ & $\begin{array}{l}1,167 \\
\text { observed } \\
\text { cases in men } \\
\text { and } 849 \text { in } \\
\text { women }\end{array}$ & $I C D$ & $\begin{array}{l}\text { Detailed occupational } \\
\text { classification with } 492 \\
\text { male groups and } 447 \\
\text { female groups }\end{array}$ & $\begin{array}{l}\text { Wood working (male): } \\
\text { RR = } 1.15 \text { (0.87-1.52); } \\
\text { chemists (female): } \\
\text { RR = } 2.32 \text { (0.85-5.04); } \\
\text { haird ressers (female) } \\
\text { RR = } 2.01 \text { (0.81-4.14) }\end{array}$ \\
\hline $\begin{array}{l}\text { 25- Linos et al., } \\
\text { 1991, USA }\end{array}$ & $\begin{array}{l}\text { Population- } \\
\text { based case- } \\
\text { control }\end{array}$ & $\begin{array}{l}\text { Cases: new cases of } \mathrm{NHL} \\
\text { and leukemia among } \\
\text { white men diagnosed } \\
\text { between } 1980 \text { and } 1983 \\
\text { in lowa and Minnesota; } \\
\text { controls: frequency matched } \\
\text { by year of birth, vital status, } \\
\text { state of residence and year } \\
\text { of death, from RDDvi ( }<65 \\
\text { years) and from Health Care } \\
\text { Finance Administration ( } \geq 65\end{array}$ & $\begin{array}{l}\text { Cases: } 572 \\
\text { N HL and } 520 \\
\text { leukemia } \\
\text { cases; } \\
\text { controls: } 1,130 \\
\text { years) }\end{array}$ & $\begin{array}{l}\text { Diagnoses } \\
\text { reviewed by } \\
\text { a panel of } \\
\text { pathologists }\end{array}$ & $\begin{array}{l}\text { Q uestionnaires ap plied } \\
\text { to study subjects or } \\
\text { their next-of-kin; } \\
\text { exposure: location of } \\
\text { residence within } 3.2 \text { and } \\
\text { within } 0.8 \mathrm{Km} \text { from } \\
\text { a factory }\end{array}$ & $\begin{array}{l}\text { Factory within } 3.2 \mathrm{Km} \\
\text { chemical: } 18 \mathrm{EC}, \mathrm{RR}=1.0 \\
(0.6-1.9) ; \text { petroleum: } \\
14 \mathrm{EC}, \mathrm{RR}=1.5(0.7-3.2) ; \\
\text { rubber: } 11 \mathrm{EC}, \mathrm{RR}=0.6 \\
(0.3-1.3)\end{array}$ \\
\hline $\begin{array}{l}\text { 26- Wolff, } \\
\text { 1992, UK }\end{array}$ & Ecological & $\begin{array}{l}\text { Lympho-hematopoietic } \\
\text { neoplasm incidence } \\
\text { in } 22 \text { counties in the UK, } \\
1984 / 1988\end{array}$ & $\begin{array}{l}2,415 \text { low } \\
\text { grade and } \\
2,550 \text { high } \\
\text { grade } \mathrm{NHL} ; \\
21,072 \text { total } \\
\text { neoplasms }\end{array}$ & $\mathrm{NHL}$ & $\begin{array}{l}\text { Car ownership by county, } \\
1981 \text { (Great Britain } \\
\text { Population Census and } \\
\text { Transport Statistics) }\end{array}$ & $\begin{array}{l}\text { Spearman rank correlation } \\
\text { coefficients: low grade } \\
\text { N HL: } 0.66 p<0.001 \text { (cars per } \\
\text { household); } 0.68 p<0.001 \\
\text { (cars per thousands) high } \\
\text { grade N HL: } 0.21 \text { and } 0.08 \\
p>0.05 \text { respectively }\end{array}$ \\
\hline $\begin{array}{l}\text { 27- Eriksson et al., } \\
\text { 1992, Sweden }\end{array}$ & Cohort & $\begin{array}{l}\text { People followed up for } \\
\text { cancer incidence from } \\
1971 \text { to } 1984 \text { (Swedish } \\
\text { Cancer-Environment } \\
\text { Registry) with } \\
\text { occupational information } \\
\text { from } 1970 \text { census }\end{array}$ & $\begin{array}{l}1,082 \mathrm{NHL} \\
\text { ( } 830 \text { men } \\
252 \text { wo men); } \\
317 \mathrm{HD} \text { and } \\
684 \mathrm{Mmii}\end{array}$ & $\begin{array}{l}\text { ICD 7th } \\
200-203\end{array}$ & Occupational groups & $\begin{array}{l}\text { Carpenter: } 149 \text { observed } \\
\text { cases, SIRiii }=1.2(1.0-1.5)\end{array}$ \\
\hline
\end{tabular}


Table1 (cont.)

\begin{tabular}{|c|c|c|c|c|c|c|}
\hline $\begin{array}{l}\text { Authors/year/ } \\
\text { country }\end{array}$ & Design & Source population & $\begin{array}{l}\text { Study } \\
\text { Subjects }\end{array}$ & $\begin{array}{l}\text { Disease } \\
\text { Classification }\end{array}$ & Exposure & Results \\
\hline $\begin{array}{l}\text { 28- Santos-Burgoa } \\
\text { et al., 1992, US }\end{array}$ & $\begin{array}{l}\text { Nested } \\
\text { case-control }\end{array}$ & $\begin{array}{l}\text { Cases: fatal lymphatic } \\
\text { and hemato poietic } \\
\text { malignancies in male } \\
\text { workers of } 8 \text { North } \\
\text { American styrene- } \\
\text { butadiene plants, } \\
\text { within a cohort of } \\
13,686 \text { workers, } \\
\text { between 1943-1982; } \\
\text { controls: matched by year } \\
\text { of hire, date of death, } \\
\text { age and duration of work, } \\
\text { selected from the same } \\
\text { cohort among causes of } \\
\text { death other than neoplasms }\end{array}$ & $\begin{array}{l}\text { Cases: } 59 \\
\text { lymphohe- } \\
\text { matopoietic } \\
\text { cancers and } \\
15 \mathrm{NHL} \text {; } \\
\text { controls: } 193 \\
\text { (total) }\end{array}$ & $\begin{array}{l}\text { ICD } 8^{\text {th }} \\
200 \text { and } 202\end{array}$ & $\begin{array}{l}\text { Personal records + panel } \\
\text { of } 4 \text { chemical engineers } \\
\text { to form J EM vii; yes/no } \\
\text { exposure, exposure rank } \\
\text { from } 0 \text { to } 10 \text { and } \\
\text { continuos/discontinuous } \\
\text { exposure }\end{array}$ & $\begin{array}{l}\text { Ever/never exposure } \\
\text { to styrene: } \\
\text { lymphossarcoma: } \\
\mathrm{OR}=1.39 \text { (0.13-3.92); } \\
\text { other lymphoma } \\
\text { (includes myeloma): } \\
\mathrm{OR}=2.42(0.50-11.6)\end{array}$ \\
\hline $\begin{array}{l}\text { 29- Scherr et al., } \\
\text { 1992, USA }\end{array}$ & $\begin{array}{l}\text { Hospital- } \\
\text { based case- } \\
\text { control }\end{array}$ & $\begin{array}{l}\text { Cases: all new cases of } \\
\text { NHL diagnosed from } \\
\text { J anuary/1980 to May/ } \\
1982 \text { among residents of } \\
\text { Boston Metro politan Area } \\
\text { who were treated in one of } \\
\text { the nine participating hospita } \\
\text { controls: matched by age, } \\
\text { sex, town and precinct of } \\
\text { residence, randomly selected } \\
\text { from town residence list }\end{array}$ & $\begin{array}{l}\text { Cases: } 303 \\
\text { (152 males and } \\
151 \text { females; } \\
\text { controls: } 303 \\
\text { als; } \\
\text { d }\end{array}$ & $\begin{array}{l}\mathrm{NHL} \\
\text { reviewed } \\
\text { by a panel of } \\
\text { pathologists; } \\
\text { Rappaport } \\
\text { (modified)and } \\
\text { International } \\
\text { Working } \\
\text { Formulation }\end{array}$ & $\begin{array}{l}\text { Questionnaires directly } \\
\text { applied to cases }(67 \%), \\
\text { to cases' proxies }(31 \%) \\
\text { and to cases' guardians } \\
(2 \%) ; \text { no information } \\
\text { regard distribution } \\
\text { of the interviews in } \\
\text { control group; } \\
\text { occupations and agents }\end{array}$ & $\begin{array}{l}\text { gasoline or kerosene: } \\
\text { OR }=1.0(0.6-1.7) ; \\
\text { benzene: } \mathrm{OR}=1.2 \\
(0.5-2.6) ; \text { chorinated } \\
\text { solvents: } \mathrm{OR}=1.2 \\
(0.8-1.8) ; \text { metal industry: } \\
\mathrm{OR}=1.2(0.6-2.5) ; \\
\text { machinery: } \mathrm{OR}=0.8 \\
(0.4-1.4) ; \text { shipbuilding, } \\
\text { auto: } \mathrm{OR}=1.0(0.6-1.7) ; \\
\text { chemicals, drugs and } \\
\text { paints: } \mathrm{OR}=0.3(0.1-0.9) ; \\
\text { leather: } \mathrm{OR}=2.1(0.9-4.8) ; \\
\text { dry cleaning: OR }=1.6 \\
(0.6-4.0) ; \text { painter and } \\
\text { plasterer: OR }=6.0 \\
(0.9-38) ; \text { carpenter, brick } \\
\text { and stone mason, plumber } \\
\text { and roofer: } \mathrm{OR}=12.0 \\
(2.0-72) ; \text { airplane or auto } \\
\text { mechanic, gas station } \\
\text { attendant: OR = } 1.4 \\
(0.6-3.6)\end{array}$ \\
\hline $\begin{array}{l}\text { 30- Partanen et al., } \\
\text { 1993, Finland }\end{array}$ & $\begin{array}{l}\text { Nested } \\
\text { case-control }\end{array}$ & $\begin{array}{l}\text { Cases: malignant } \\
\text { lymphomas and } \\
\text { leukemias notified } \\
\text { to the Finnish Cancer } \\
\text { Registry, diagnosed in } \\
\text { wood male workers of } \\
35 \text { plants, within a cohort } \\
\text { of } 7,307 \text { workers, between } \\
1957-1982 ; \text { controls: } \\
\text { matched by year of birth } \\
\text { and survival/non-survival } \\
\text { status in } 1983 \text {, selected } \\
\text { from the same cohort }\end{array}$ & $\begin{array}{l}\text { Cases: } 8 \mathrm{NHL} \text {; } \\
4 \text { HD and } 12 \\
\text { leukemia cases; } \\
\text { controls: } 152 \\
\text { ( } 52 \text { for the } \\
\text { N HL cases) }\end{array}$ & $\begin{array}{l}\text { ICD: } 200 \text {, } \\
202\end{array}$ & $\begin{array}{l}\text { Individual exposure to } \\
\text { solvents and to other } \\
\text { agents reconstructed } \\
\text { using a plant/period- } \\
\text { specific J EM (cases and } \\
\text { controls); interviews of } \\
\text { persons at the plants + } \\
\text { questionnaires (only cases } \\
\text { or their next-of-kin) }\end{array}$ & $\begin{array}{l}\text { Unidentified solvents: } \\
\text { leukemias and lymphomas } \\
\text { pooled: } 4 \mathrm{EC}, \mathrm{OR}=5.62 \\
\text { (0.99-32.0); adjustment for } \\
\text { formaldehyde exposure: } \\
\text { OR }=5.07(0.40-63.5) ; \\
\text { NHL: } 2 \mathrm{EC} \text { and no } \\
\text { exposed controls }\end{array}$ \\
\hline $\begin{array}{l}\text { 31- Persson et al., } \\
\text { 1993, Sweden }\end{array}$ & $\begin{array}{l}\text { Hospital- } \\
\text { based case- } \\
\text { control }\end{array}$ & $\begin{array}{l}\text { Cases: NHL and HD } \\
\text { occurred in men living } \\
\text { in Ö sterg ötland, } \\
\text { J önköping and Kalmar } \\
\text { counties, obtained from } \\
\text { the Regional Cancer } \\
\text { Registry at the University } \\
\text { Hospital in Linköping, } \\
\text { diagnosed between 1975/ } \\
\text { 1984, alive in 1986, } \\
\text { aged 20-80; controls: from } \\
\text { the population registry, } \\
\text { resident in the same catchme } \\
\text { area of the cases }\end{array}$ & $\begin{array}{l}\text { Cases: } 93 \mathrm{NHL} \\
\text { and } 31 \mathrm{HD} ; \\
\text { controls: } 204\end{array}$ & $\begin{array}{l}\text { ICD 8th: } \\
200.0,200.1 \\
\text { and } 200.2\end{array}$ & $\begin{array}{l}\text { Posted questionnaires; } \\
\text { Five levels of solvent } \\
\text { exposure, at least for } \\
1 \text { year }\end{array}$ & $\begin{array}{l}\text { Solvents occupational: } \\
O R=1.2(28 / 53 \text { exposed } \\
\text { cases/controls) and } \\
\text { intensity categoriy } \\
2-5 \times 0-1(24 / 34) \\
O R=1.7 O R_{\text {log }}=1.1 \\
(0.6-2.2) ; \text { white spirit: } \\
O R=1.6(14 / 20) ; \text { aviation } \\
\text { gasoline: } O R=3.0(4 / 3) ; \\
\text { solvents non-occupational: } \\
O R=3.4(3 / 2) ; \text { carpenter/ } \\
\text { cabinet makers: } O R=1.0, \\
O R_{\text {log }}=0.9(0.4-2.1) \\
(11 / 25)\end{array}$ \\
\hline
\end{tabular}


Table1 (cont.)

\begin{tabular}{|c|c|c|c|c|c|c|}
\hline $\begin{array}{l}\text { Authors/year/ } \\
\text { country }\end{array}$ & Design & Source population & $\begin{array}{l}\text { Study } \\
\text { Subjects }\end{array}$ & $\begin{array}{l}\text { Disease } \\
\text { Classification }\end{array}$ & Exposure & Results \\
\hline $\begin{array}{l}\text { 32- Blair et al., } \\
\text { 1993, USA }\end{array}$ & $\begin{array}{l}\text { Population- } \\
\text { based case- } \\
\text { control }\end{array}$ & $\begin{array}{l}\text { Cases: NHL in white men, } \\
\text { reported to the lowa State } \\
\text { Health Registry, } 1981 \text { to } \\
1983 ; \text { NHL in white men } \\
\text { diagnosed between } 1980 \text { to } \\
1982 \text { at a network of hospital } \\
\text { in Minnesota; contro Is: } \\
\text { frequency matched by age, } \\
\text { year of death for deceased c } \\
\text { and state, from RDD, medica } \\
\text { files and listings of death }\end{array}$ & $\begin{array}{l}\text { Cases: 622; } \\
\text { controls: 1,245 } \\
\text { als } \\
\text { cases } \\
\text { are }\end{array}$ & $\begin{array}{l}\text { Cases } \\
\text { reviewed } \\
\text { by a panel of } \\
\text { pathologists } \\
\text { and classified } \\
\text { according } \\
\text { to the } \\
\text { International } \\
\text { Working } \\
\text { Formulation }\end{array}$ & $\begin{array}{l}\text { Questionnaires directly } \\
\text { applied to cases and } \\
\text { controls or their surrogates; } \\
\text { job titles, industries and } \\
\text { industrial hygienist } \\
\text { judgment; pro bability of } \\
\text { exposure (4 levels) and } \\
\text { intensity of exposure } \\
\text { (3 levels) }\end{array}$ & 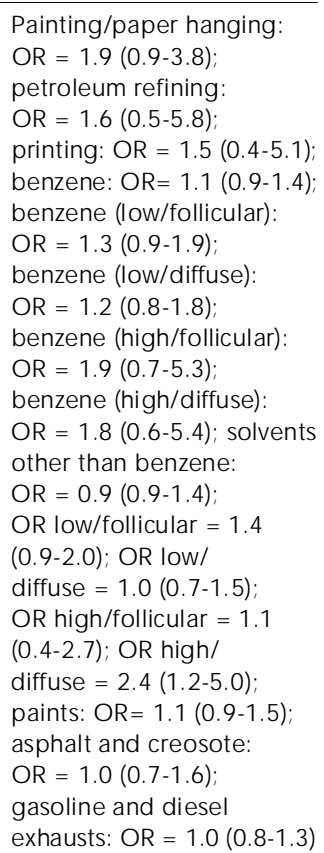 \\
\hline
\end{tabular}

33- Linet et al. 1993, Sweden

\section{Cohort}

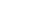

People followed up for
cancer incidence from
1961 to 1979 (Swedish

1961 to 1979 (Swedish

Registry) with occupationa

information from 1960 census

\begin{tabular}{|c|c|c|c|}
\hline $\begin{array}{l}4,496 \\
\text { observed cases } \\
\text { in employed } \\
\text { Swedish men } \\
\text { us }\end{array}$ & $\begin{array}{l}\mathrm{NHL} \\
\text { microscop- } \\
\text { ically } \\
\text { verified }\end{array}$ & $\begin{array}{l}\text { Industrial and occupational } \\
\text { categories derived from } \\
\text { international standards }\end{array}$ & $\begin{array}{l}\text { Shoe repair industry: } \\
23 \text { cases, } S I R=1.8 p<0.05 \\
\text { shoemakers: } 23 \text { cases, } \\
\text { SIR }=1.7 p<0.05 \\
\text { porcelain and earthenware: } \\
14 \text { cases, } S I R=1.9 p<0.05 \\
\text { furniture maker: } 44 \text { cases, } \\
\text { SIR }=1.3 p<0.01 \\
\text { lorry drivers: } 42 \text { cases, } \\
\text { SIR }=1.4 p<0.01\end{array}$ \\
\hline
\end{tabular}

1,174 NHL observed cases microscopin employed ically Swedish verified

Industrial and occupational Furniture and finishing categories derived from international standards industry: 4 cases, $\mathrm{SIR}=1.5$; graphics industry and publishing business: 15 cases, $\mathrm{SIR}=0.7$; rubber industry: 5 cases, SIR $=1.1$; chemical industry: 9 cases, $\mathrm{SIR}=0.8$; machine and electronics industry: 26 cases, $\operatorname{SIR}=0.8$; shoe and leather workers: 10 cases, $\mathrm{SIR}=1.4$ 
Table1 (cont.)

\begin{tabular}{|c|c|c|c|c|c|c|}
\hline $\begin{array}{l}\text { Authors/year/ } \\
\text { country }\end{array}$ & Design & Source population & $\begin{array}{l}\text { Study } \\
\text { Subjects }\end{array}$ & $\begin{array}{l}\text { Disease } \\
\text { Classification }\end{array}$ & Exposure & Results \\
\hline $\begin{array}{l}\text { 35- Kolstad et al., } \\
\text { 1994, Denmark }\end{array}$ & Cohort & $\begin{array}{l}\text { Exposed group: male } \\
\text { workers employed any } \\
\text { time from } 1964 \text { to } 1988 \\
\text { in } 386 \text { reinforced plastic } \\
\text { industry and resident in } \\
\text { Denmark after } 01 / 01 / 70, \\
\text { followed up until } 12 / 31 / 89 ; \\
\text { non-exposed group: } \\
\text { general population }\end{array}$ & $\begin{array}{l}\text { Exposed } \\
\text { group: } \\
53,720(584 \\
556 \mathrm{p} / \mathrm{y}) \\
\end{array}$ & $\begin{array}{l}\text { ICD 7th } \\
200-205\end{array}$ & $\begin{array}{l}\text { Styrene exposure in } \\
\text { reinforced plastic industry; } \\
2,473 \text { personal air samples } \\
\text { from work sites during } \\
1964-1970,1971-1975 \text { and } \\
1976-1988 \text { with the mean } \\
\text { styrene levels: } 180,88 \\
\text { and } 43 \text { ppm (1814 were } \\
\text { sampled from companies } \\
\text { included in the study) }\end{array}$ & 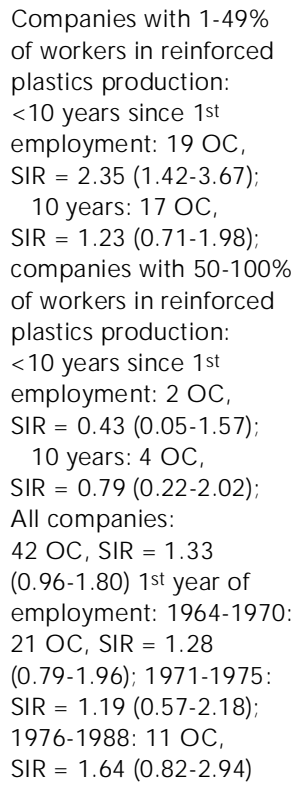 \\
\hline
\end{tabular}

36- Hardell et al., 1994, Sweden

\section{Hospital-} based casecontrol
Cases: all men admitted to the Department of Oncology in Umea years old; controls: 8 matched (age, sex, residence) controls for each living case and 10 matched (age, sex, residence and year of death) from the $\mathrm{N}$ ational Population Registry (catchment area), 25-85
Cases: 105;

controls: 335

Rappaport

Self administered
questionnaires,

supplemented by

1 week continuously or less than 1 month in total); high (more than that) telephone. Low (less than

Carpenter: 13 exposed cases/36 exposed controls, $\mathrm{OR}=1.1$ (0.6-2.4); mechanic: $5 / 7$, $\mathrm{OR}=2.5$ (0.7-9.6);

motor mechanic: $7 / 20$, $\mathrm{OR}=1.3$ (0.5-3.4); all organic solvents: $45 / 88$, $\mathrm{OR}=2.4$ (1.4-3.9); high grade: $31 / 50, O R=2.9$ (1.6-5.6); low grade: $14 / 38,0 R=1.8(0.8-3.8) ;$ benzine: $3 / 1, O R=2.8$ (1.8-730); thinner: $11 / 14$, OR = 3.4 (1.4-10); trichloro ethylene: $4 / 4$, $\mathrm{OR}=7.2(1.3-42)$; turpentine: $5 / 7, O R=3.3$ (0.9-17); white spirit: $12 / 20$, O R $=3.2(1.3-8.3)$; degreaser: $7 / 4, O R=11$ (2.9-72); multivariate analysis - high grade: $\mathrm{OR}=3.5$ (1.7-7.1); low grade: $O R=1.1(0.5-2.7)$; organic solvents (lymphocytic, well differentiated $\mathrm{NHL}$ ): $\mathrm{OR}=2.9(1.3-6.6)$

\begin{tabular}{|c|c|c|c|c|c|c|}
\hline $\begin{array}{l}\text { 37- Figgs et al., } \\
1995, \text { USA }\end{array}$ & $\begin{array}{l}\text { Death } \\
\text { certificate- } \\
\text { based case- } \\
\text { control }\end{array}$ & $\begin{array}{l}\text { Cases: NHL deaths } \\
\text { among residents from } 24 \\
\text { American states between } \\
\text { 1984-1989; controls: } \\
5 \text { matched non-cancer } \\
\text { deaths }\end{array}$ & $\begin{array}{l}\text { Cases: } 23,890 \\
\text { controls } \\
119,450\end{array}$ & $\begin{array}{l}\text { NHL } \\
(\text { ICD 9th }= \\
200 \text { and } \\
202 \text {, except } \\
202.3 \text { and } \\
202.6)\end{array}$ & $\begin{array}{l}\text { Industries and occupations } \\
\text { obtained from death } \\
\text { certificates }\end{array}$ & $\begin{array}{l}\text { White men: aircraft } \\
\text { mechanics: } 8 \mathrm{EC}, \mathrm{OR}=2.5 \\
(1.1-6.0) \text {; farm equipment } \\
\text { mechanics: } 7 \mathrm{EC}, \mathrm{OR}=2.1 \\
(0.9-5.3) \text {; electronic repairs: } \\
12 \mathrm{EC}, \mathrm{OR}=2.1(1.1-4.1) \text {; } \\
\text { miscellaneous electronic } \\
\text { and electrical repairs: } \\
10 \mathrm{EC}, \mathrm{OR}=2.0(1.0-4.3) \text {; } \\
\text { painters: } 65 \mathrm{EC}, \mathrm{OR}=0.6 \\
\text { (0.5-0.8); black men: ship/ } \\
\text { boat building and repair: } \\
7 \mathrm{EC}, \mathrm{OR}=2.9(1.1-7.9)\end{array}$ \\
\hline
\end{tabular}


Table1 (cont.)

\begin{tabular}{|c|c|c|c|c|c|c|}
\hline $\begin{array}{l}\text { Authors/year/ } \\
\text { country }\end{array}$ & Design & Source population & $\begin{array}{l}\text { Study } \\
\text { Subjects }\end{array}$ & $\begin{array}{l}\text { Disease } \\
\text { Classification }\end{array}$ & Exposure & Results \\
\hline $\begin{array}{l}\text { 38- Hours et al., } \\
\text { 1995, France }\end{array}$ & $\begin{array}{l}\text { Hospital- } \\
\text { based case- } \\
\text { control }\end{array}$ & $\begin{array}{l}\text { Cases: hematological } \\
\text { malignancies diagnosed } \\
\text { in both sexes, aged } \\
30-74, \text { between } 01 / 01 / 81- \\
12 / 31 / 87 \text { in } 2 \text { hospitals } \\
\text { in Lyon; controls: } 1: 1 \\
\text { matched non-cancer and } \\
\text { non- occupationally } \\
\text { diseased patients by sex, } \\
\text { age and nationality from } \\
\text { the same hospitals }\end{array}$ & $\begin{array}{l}\text { Cases: } 52 \\
\text { N HL; } 48 \text { AM L2 } \\
\text { leukemia and } \\
18 \text { other } \\
\text { leukemias }\end{array}$ & & $\begin{array}{l}\text { Occupational exposures } \\
\text { to } 320 \text { compounds; } \\
\text { questionnaires }+ \\
\text { evaluation by experts } \\
\text { in chemistry and } \\
\text { occupational medicine; }\end{array}$ & $\begin{array}{l}\text { Mononuclear aromatic } \\
\text { hydrocarbon: } 13 \mathrm{EC} \text {, } \\
\mathrm{OR}=2.10 \mathrm{p}=0.23 ; \\
\text { polynuclear aromatic } \\
\text { hydrocarbon: } 30 \mathrm{EC} \\
\mathrm{OR}=0.76 \mathrm{p}=? ; \mathrm{BTX} \text { mix: } \\
6 \mathrm{EC}, \mathrm{OR}=14.86 \mathrm{p}<0.01 ; \\
\text { inks: } 20 \mathrm{EC}, \mathrm{OR}=2.47 \\
\mathrm{P}=0.02 ; \text { varnish and } \\
\text { paints: } 6 \mathrm{EC}, \mathrm{OR}=2.55 \\
p=0.08\end{array}$ \\
\hline $\begin{array}{l}\text { 39- Hunting et al., } \\
\text { 1995, USA }\end{array}$ & $\begin{array}{l}\text { Cohort } \\
\text { mortality }\end{array}$ & $\begin{array}{l}338 \text { male employees } \\
(3,813 \mathrm{p} / \mathrm{y}) \text { of the fleet } \\
\text { maintenance division of } \\
\text { the DC's Department of } \\
\text { Public Works (DPW), } \\
\text { employed for at least } 1 \\
\text { year between } 1 / 1 / 7 \text { - } \\
12 / 31 / 91\end{array}$ & $\begin{array}{l}9 \text { cancer and } \\
3 \text { lymphatic and } \\
\text { hematopoietic } \\
\text { deaths (1 N HL } \\
\text { death) }\end{array}$ & ICD 9th & $\begin{array}{l}\text { Low, medium or high } \\
\text { potential exposure to } \\
\text { fuels and solvents } \\
\text { according to personal } \\
\text { records data and DPW } \\
\text { and union representatives } \\
\text { discussion }\end{array}$ & $\begin{array}{l}\text { Lymphatic and } \\
\text { hematopoietic cancers: } \\
3 \text { cases SMR }=4.22 \\
(0.87-12.34) \text { N HL: } 1 \text { case } \\
\text { SMR }=2.57 \text { (0.06-14-27) }\end{array}$ \\
\hline $\begin{array}{l}\text { 40- Yin et al. } \\
\text { 1996, China }\end{array}$ & $\begin{array}{l}\text { Multicenter } \\
\text { retrospective } \\
\text { cohort }\end{array}$ & $\begin{array}{l}\text { Exposed group: } \\
\text { benzene-exposed } \\
\text { workers employed from } \\
1 / 1 / 72 \text { to } 12 / 31 / 87 \text { in } \\
672 \text { factories in } 12 \text { Chinese } \\
\text { cities; unexposed group: } \\
\text { workers from } 109 \text { factories } \\
\text { in the same period and } \\
\text { places }\end{array}$ & $\begin{array}{l}\text { Exposed } \\
\text { group: } \\
74,828 \\
\text { workers; } \\
\text { unexposed } \\
\text { group: } 35,805 \\
\text { workers }\end{array}$ & $\begin{array}{l}\text { International } \\
\text { Working } \\
\text { Formulation }\end{array}$ & $\begin{array}{l}\text { Work units; job titles; } \\
\text { monitoring data; list of } \\
\text { row material and factory } \\
\text { products; engineering } \\
\text { control; personal } \\
\text { protective equip.; } \\
\text { estimated exposures } \\
\text { in ppm }\end{array}$ & $\begin{array}{l}\text { Mortality: } 17 \mathrm{EC} ; \mathrm{RR}=4.5 \\
\text { (1.3-28.4); incidence: } \\
20 \mathrm{EC} ; \mathrm{RR}=3.5(1.3-14.9)\end{array}$ \\
\hline $\begin{array}{l}\text { 41- Schnatter, } \\
\text { 1996, Canada }\end{array}$ & $\begin{array}{l}\text { Nested case- } \\
\text { control }\end{array}$ & $\begin{array}{l}\text { Cases: all male NHL } \\
\text { deaths from a cohort } \\
\text { of petroleum workers; } \\
\text { controls: } 4: 1 \text { from the } \\
\text { same cohort matched } \\
\text { by decade of birth }\end{array}$ & $\begin{array}{l}\text { Cases: } 31 \\
\text { lympho- } \\
\text { haematopoi- } \\
\text { etic including } \\
8 \text { NHL; } \\
\text { controls: } 124 \text {, } \\
32 \text { for NHL } \\
\text { cases }\end{array}$ & $\begin{array}{l}\text { ICD 8th : } \\
200,202.0 \\
202.1,202.2 \\
\text { and } 202.9\end{array}$ & $\begin{array}{l}\text { Benzene and total } \\
\text { hydrocarbon exposures; } \\
\text { personal records + } \\
\text { evaluation by experts } \\
\text { in industrial hygiene; } \\
\text { estimated exposures } \\
\text { in ppm }\end{array}$ & $\begin{array}{l}\text { Total hydrocarbons, } \\
\text { cumulative exposure in } \\
\text { pmm-y: } 0-11.6 \text { OR }=1 ; \\
11.7-29.9 \text { OR }=1.73 \\
(0.02-137) ; 30-549 \text { OR }=0 ; \\
550-6721 \text { OR }=1.22 \\
(0.01-137) ; \text { benzene: } \\
0-0.49 \text { OR }=1 ; 0.50-7.99 \\
\text { OR = 1.21 (0.16-8.07); } \\
8-19 . .99 \text { OR }=1.14 \\
(0.02-27.6) ; 20-219.8 \\
\text { OR }=0 ; \text { benzene (mean } \\
\text { ppm): } 0-0.01 \text { OR }=1 ; \\
>0.01-0.19 \text { OR }=1.25 \\
(0.10-11.3) ; 0.20-0.49 \\
\text { OR }=0.97(0.08-7.58) ; \\
0.50-6.16 \text { OR }=0 ; \text { benzene } \\
(\text { maximum intensity in } \\
\text { ppm): }<0.5 \text { OR }=1 ; \\
0.51-0.99 \text { OR }=5.85 \\
(0.30-354) ; \geq 1.0 \text { OR }=0.54 \\
(0.01-5.94)\end{array}$ \\
\hline
\end{tabular}


Table1 (cont.)

\begin{tabular}{|c|c|c|c|c|c|c|}
\hline $\begin{array}{l}\text { Authors/year/ } \\
\text { country }\end{array}$ & Design & Source population & $\begin{array}{l}\text { Study } \\
\text { Subjects }\end{array}$ & $\begin{array}{l}\text { Disease } \\
\text { Classification }\end{array}$ & Exposure & Results \\
\hline $\begin{array}{l}\text { 42- Fritschi \& } \\
\text { Siemiatycki, } \\
\text { 1996, Canada }\end{array}$ & $\begin{array}{l}\text { Registry- } \\
\text { based case- } \\
\text { control }\end{array}$ & $\begin{array}{l}\text { Cases: all new male cases } \\
\text { diagnosed between 1979- } \\
1985, \text { aged 35-70, resident } \\
\text { in Montreal; controls: from } \\
\text { other cancer patients, } \\
\text { except lung cancer and } \\
\text { from electoral list or } \\
\text { by RDD }\end{array}$ & $\begin{array}{l}\text { Cases: } 258 \\
\text { eligible and } \\
215 \text { interviewed; } \\
\text { controls: } 2,357 \\
\text { from the cancer } \\
\text { registry and } \\
740 \text { from } \\
\text { population with } \\
533 \text { interviewed }\end{array}$ & NHL & $\begin{array}{l}\text { Questionnaires + } \\
\text { evaluation by a team of } \\
\text { chemists and industrial } \\
\text { hygienists; confidence } \\
\text { of exposure: possible, } \\
\text { probable and definite; } \\
\text { frequency of exposure: } \\
<5 \%, 5-30 \% \text { and }>30 \% \text {; } \\
\text { and the level of the } \\
\text { agent at the workplace; } \\
\text { classification of } \\
\text { occupations and } \\
\text { industries }\end{array}$ & $\begin{array}{l}\text { Benzene: low level: } 20 \mathrm{EC} \text {, } \\
\text { OR }=0.7(0.4-1.1) ; \text { high } \\
\text { level: } 6 \mathrm{EC}, \mathrm{OR}=0.8 \\
(0.3-2.1) ; \text { solvents: low } \\
\text { level: } 26 \mathrm{EC}, \mathrm{OR}=0.6 \\
(0.4-1.0) ; \text { high level: } 48 \mathrm{EC} \\
\text { OR }=0.9(0.6-1.3) ; \\
\text { carpenters: } 1-9 \text { years: no } \\
\text { cases; } 10+\text { years: } 4 \mathrm{EC}, \\
\text { OR }=0.8(0.3-2.2) ; \\
\text { furniture: } 1-9 \text { years: } 1 \mathrm{EC}, \\
\text { OR }=0.4(0.1-3.4) ; 10+ \\
\text { years: } 3 \mathrm{EC}, \mathrm{OR}=1.6 \\
(0.4-6.1) ; \text { rub ber and } \\
\text { plastic workers: } 1-9 \text { years: } \\
4 \mathrm{EC}, \mathrm{OR}=3.6(0.9-15.0) ; \\
10+\text { years: } 1 \mathrm{EC}, \mathrm{OR}=9.0 \\
(0.6-148.0)\end{array}$ \\
\hline
\end{tabular}

43- Massoudi
et al., 1997, USA

\section{Death certificate- based case-} control

\section{Cases: lymphatic and} hematopoietic cancer in white male, aged 23-96 who had died between 1965-1990 and lived in Kanawha County (West Virginia); controls: matched 1:1 card io vascular disease patients with the same characteristics
Cases: 309 lymphatic and hematopoietic cancers (106 $\mathrm{NHL})$; controls: 106 106
NHL (ICD 9th Industries and occupations 200, 202)

reviewed by a pathologist obtained from death certificates and validated

by interviewing next of kin; 3 categ ories of exposure: chemical manufacturing workers; those exposed to chemicals at other jobs; those not exposed

Chemical workers $X$ not exposed: unstratified: $\mathrm{OR}=1.52(0.8-2.8)$,

$p=0.168 ;<65: 50 \mathrm{MP}$,

$O R=3.11(1.1-8.8)$, $\mathrm{p}=0.03 ; \geq 65: 56 \mathrm{MP}$ $O R=0.97(0.5-2.1)$, $p=0.94$

\begin{tabular}{ll}
\hline 44- Holly et al., & Population- \\
1997, USA & based case- \\
& control
\end{tabular}

Cases: NHL in homosexual Cases: 312

$\mathrm{NHL}$ men; controls: ho mosexual $\mathrm{NHL}$; men, matched by age controls: 420 within five years and county of residence

Chemical and
occupational exposures
from questionnaires

from questionnaires

\author{
Petroleum products, HIV+ \\ men: $\mathrm{OR}=0.37$ \\ (0.18-0.72), 10-499 hours; \\ $\mathrm{OR}=0.61(0.34-1.1)$, \\ $>500$ h; HIV- men: \\ $O R=1.6(0.69-3.6)$, \\ $10-499 \mathrm{~h} ; \mathrm{OR}=0.94$ \\ (0.37-2.4); gasoline, HIV+ \\ men: $\mathrm{OR}=0.65(0.36-1.2)$, \\ $>10 \mathrm{~h}$; HIV - men: \\ $\mathrm{O} R=1.7(0.72-4.0)$; \\ Kerosene and other oils, \\ HIV+ men: $O R=0.72$ \\ (0.36-1.5), >100 h; \\ HIV - men: $O R=1.3$ \\ $(0.52-3.1),>100 \mathrm{~h}$; \\ ald ehydes, cleaning \\ solvents and adhesives, \\ HIV + men: $\mathrm{OR}=0.60$ \\ $(0.32-1.1), 10-249 \mathrm{~h}$; \\ $O R=0.52(0.29-0.93)$, \\ $>250$ h; HIV - men: \\ $O R=1.0(0.47-2.2)$, \\ 10-249 h; OR = 1.5 \\ (0.69-3.1), >250 h; \\ benzene, all men: \\ $\mathrm{OR}=1.2(0.62-2.4),>10 \mathrm{~h}$; \\ chlorinated solvents, all \\ men: $O R=0.73(0.41-1.3)$
}


Table1 (cont.)

\begin{tabular}{|c|c|c|c|c|c|c|}
\hline $\begin{array}{l}\text { Authors/year/ } \\
\text { country }\end{array}$ & Design & Source population & $\begin{array}{l}\text { Study } \\
\text { Subjects }\end{array}$ & $\begin{array}{l}\text { Disease } \\
\text { Classification }\end{array}$ & Exposure & Results \\
\hline $\begin{array}{l}\text { 45- Tatham et al., } \\
1997 \text {, USA }\end{array}$ & $\begin{array}{l}\text { Population- } \\
\text { based case- } \\
\text { control }\end{array}$ & $\begin{array}{l}\text { Cases: NHL in men from } \\
\text { eight cancer registries } \\
\text { between December/1984- } \\
\text { November/1988; controls: } \\
\text { matched by date of birth } \\
\text { (five years) through random } \\
\text { digit dialing }\end{array}$ & $\begin{array}{l}\text { Cases: } 1,048 \\
\text { N HL (185 small } \\
\text { cell diffuse } \\
\text { lymphomas; } \\
268 \text { follicular } \\
\text { and lymphomas } \\
526 \text { large } \\
\text { cell diffuse } \\
\text { lymphomas); } \\
\text { controls: } 1,659 \\
\text { individuals }\end{array}$ & $\begin{array}{l}\text { Subtypes } \\
\text { of NHL } \\
\text { defined by } \\
\text { a panel of } \\
\text { pathologists }\end{array}$ & $\begin{array}{l}\text { Telephone interview. } \\
\text { Time of exposure for all } \\
\text { jobs with Known dates; } \\
\text { exposures were defined } \\
\text { as within } 10 \text { years and } \\
\text { more than } 10 \text { years }\end{array}$ & 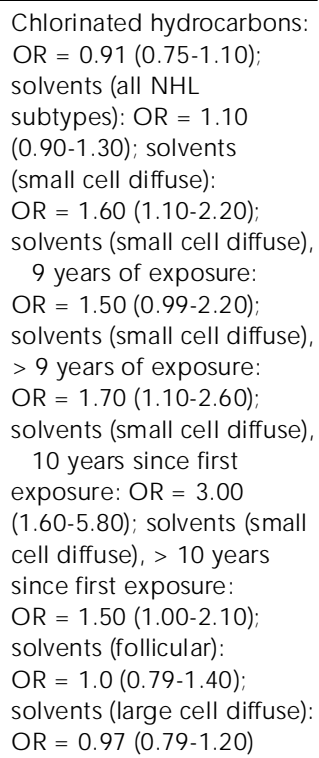 \\
\hline
\end{tabular}

\footnotetext{
i Observed/expected.
}

ii $\mathrm{RCS}=$ reticulum cell sarcoma; $\mathrm{LS}=$ lymphosarcoma; HD = Hodgkin's disease:

NHL = non-Hodgkin's lymphoma; $A L L=$ acute lymphocitic leukemia;

$C L L=$ chronic lymphocitic leukemia; $M M=$ multiple myeoma; $A M L=$ acute myeloid leukemia.

iii $R R=$ relative risk; $O R=$ odds ratio; $E C=$ exposed case; $S M R=$ standard mortality ratio;

$\mathrm{SIR}=$ standard incidence ratio.

iv International Classification of Diseases.

v Surveillance, Epidemiology and End Results Program, at N ational Cancer Institute - USA.

vi $\mathrm{RDD}=$ random digit dialing

vii $\mathrm{J}$ EM $=$ job exposure matrix.

\section{Acknowledgments}

This study was supported by CAPES (Centro de Aperfeiçoamento de Pessoal de Nível Superior), a organization of the Brazilian Government, and by the cooperation between the School of Public Health/University of North Carolina at Chapel Hill, USA and the Institute of Public Health/Federal University of Bahia Brazil. I thank the Occupational Health Center and the Petrochemical Workers Union, Bahia - Brazil. Also I thank Dr. Dana Loomis and Dr. SteveWing, assistant professors at SPH/UNC for their comments, Dr. Cláudio Sousa for his support and Dr. Brian Shelley, Dr. Luenda Charles and Dr. Rita Rêgo for the overall review.

\section{References}

BALARAJAN, R., 1983. Malignant lymphomas in road transport workers. Journal of Epidemiology and Community Health, 37:279-280.

BALARAJAN, R. \& M CDOWALL, M., 1983. Malignant lymphomas and road transport workers. Journal of Epidemiology and Community Health, 37:316.

BANKS, P. M., 1992. Changes in diagnosis of nonHodgkin's lymphomas over time. Cancer Research, 52(Sup.):5453s-5455s.

BERNARD, S. M; CARTWRIGHT, R. A; BIRD, C. C.; RICHARDS, I. D.; LAUDER, I. \& ROBERTS, B. E., 1984. Aetiologic factors in lymphoid malignancies: a case-control epidemiological study. Leukemia Research, 8:681-689. 
BINASCHI, S.; SANTORO, G. \& INTROINI, U ., 1985. Hypothesis of occupational etiology of Hodgkin's and non-Hodgkin's lymphoma: a case-control study. Giornaleltaliano di Medicina del Lavoro, 7:181-186.

BLAIR, A.; LINOS, A.; STEWART, P. A.; TOLBERT, P.; GRAUMAN, D.; MORAN, F. X.; VAUGHT, J. \& RAYNER, J., 1990. Cancer and other causes of death among a cohort of dry cleaners. British Journal of Industrial Medicine, 47:162-168.

BLAIR, A.; LINOS, A.; STEWART, P. A.; BURMEISTER, L. F.; GIBSON, R.; EVERETT, G.; SCHUMAN, L. \& CANTOR, K. P., 1992. Comments on occupational and environmental factors of non-Hodgkin'slymphoma. Cancer Research, 52(Sup.):5501s-5502s.

BLAIR, A.; LINOS, A; STEWART, P. A.; BURMEISTER, L. F.; GIBSON, R.; EVERETT, G.; SCHUMAN, L. \& CANTOR, K. P., 1993. Evaluation of risks for nonHodgkin's lymphoma by occupation and industry exposures from a case-control study. American Journal of Industrial Medicine, 23:301-312.

BOUYER, J. \& HÉM ON, D., 1993. Retrospective evaluation of occupational exposures in populationbased case-control studies: general overview with special attention to job exposure matrices. International Journal of Epidemiology, 22(Sup. 2):S57-S64.

BRANDT, L., 1987. Leukaemia and lymphoma risks derived from solvents. Medical Oncology and Tumor Pharmacotherapy, 4:199-205.

BROWNSON, R. C. \& REIF, J. S., 1988. A cancer registry-based study of occupational risk for lymphoma, multiple myeloma and leukaemia. International Journal of Epidemiology, 17:27-32.

CANTOR, K. P. \& FRAU MENI J r., J. F., 1980. Distribution of non-Hodgkin's lymphoma in the United States between 1950 and 1975. Cancer Research, 40:2645-2652.

CAPURRO, P. U., 1979. Cancer in a community subject to air pollution by solvent vapors. Clinical Toxicology, 14:285-294.

CARLI, P. M.; BOUTRON, M. C.; MAYNADIÉ, M.; BAILLY, F.; CAILLOT, D. \& PETRELLA, T., 1994. Increase in the incidence of non-Hodgkin's lymphomas: evidence for a recent sharp increase in France independent of AIDS. British Journal of Cancer; 70:713-715.

CARTWRIGHT, R. A., 1992. Changes in the descriptive epidemiology of non-Hodgkin's Iymphoma in Great Britain? Cancer Research, 52(Sup.):5441s5442s.

CARTWRIGHT, R. A.; M CKINNEY, P. A.; O'BRIEN, C.; RICHARDS, I. D. G.; ROBERTS, B.; LAUDER, I.; DARWIN, C. M.; BERNARD, S. M. \& BIRD, C. C., 1988. Non-Hodgkin's lymphoma: case-control epidemiological study in Yorkshire. Leukemia Research, 12: 81-88.

COLE, P.; DELZELL, E. \& ACQUAVELLA, J., 1993. Exposure to butadiene and lymphatic and hematopoietic cancer. Epidemiology, 4:96-103.

COSTANTINI, A. S.; BARCHIELLI, A.; CROSIGNANI, P.; VIGANO, C. \& MASALA, G., 1992. Epidemiologia e fattori di rischio, in particolare ambientali, dei linfomi maligni non Hodgkin. Gruppo di lavoro sull' epidemiologia dei tumori del sistema emolinfopoietico in Italia. Epidemi ologia e Prevenzione, 14:12-21.
COZEN, W. \& BERNSTEIN, L., 1994. The Palackdharry article reviewed. Oncology, 8:77-78.

DELZELL, E. \& MONSON, R. R., 1984. Mortality among rubber workers:VII. Industrial products workers. American Journal of Industrial Medicine, 6:273-279.

DELZELL, E.; AUSTIN, H. \& COLE, P., 1988. Epidemiologic studies of the petroleum industry. Occupational Medicine: State of the Art Reviews, 3:455474.

DEVESA, S. S. \& FEARS, T., 1992. Non-Hodgkin's lymphoma time trends: United States and international data. Cancer Research, 52(Sup.):5432s-5440s.

DICK, F.; VANLIER, S.; BANKS, P.; FRIZZERA, G.; WITRAK, G.; GIBSON, R.; EVERETT, G.; SCHUMAN, L.; ISACSON, P.; O'CONOR, G.; CANTOR, K.; BLATTNER., W. \& BLAIR, A., 1987. Use of the working formulation for non-Hodgkin's lymphoma in epidemiologic studies: agreement between reported diagnoses and a panel of experienced pathologists. Journal of the National Cancer Institute, 78:1137-1144.

DOSEMECI, M.; LI, G. L.; HAYES, R. B.; YIN, S. N.; LINET, M.; CHOW, W. H.; WANG, Y. Z.; JIANG, Z. L.; DAI, T. R.; ZHANG, W. U.; CHAO, X. J.; YE, P. Z.; KOU, Q. R.; FAN, Y. H.; ZHANG, X. C.; LIN, X. F.; MENG, J. F.; ZHO, J. S.;WACHOLDER, S.; KNELLER, R. \& BLOT, W. J., 1994. Cohort study among workers exposed to benzene in China: II. Exposure assessment. American Journal of Industrial Medicine, 26:401-411.

DUBROW, R.; PAU LSON, J. O. \& WINDIAN, R., 1988. Farming and malignant lymphoma in Hancock County, Ohio. British Journal of Industrial Medicine, 45:25-28.

ENTERLINE, P. E., 1979. Lymphomas and benzene. Lancet, 2:1021.

ERIKSSON, M.; HARDELL, L.; MALKER, H. \&WEIN$E R, J ., 1992$. Malignant lymphoproliferative diseases in occupations with potential exposure to phenoxyacetic acids or dioxins: a register-based study. American Journal of Industrial Medicine, 22:305-12.

EVERETT, G.; BLAIR, A.; CANTOR, R.; GIBSON, R. \& VAN LIER, S., 1985. Environmental chemical exposures as risk factors for leukemia and nonHodgkin's lymphoma (abstract). Ameri can Journal of Epidemiology, 122:535-536.

FIGGS, L. W.; DOSEMECI, M . \& BLAIR, A., 1995. United States non-Hodgkin's lymphoma surveillance by occupation 1984-1989: a twenty-four state death certificate study. American Journal of Industrial Medicine, 27:817-835.

FRANCESCHI, S.; SERRAINO, D.; BIDOLI, E.; TALAMINI, R.; TIRELLI, U .; CARBONE, A. \& LA VECHIA, C., 1989. The epidemiology of non-Hodgkin's lymphoma in the north-east of Italy: a hospital based case-control study. Leukemia Research, 13:465472.

FRANCO, G. \& PONTE, R., 1983. Malignant lymphomasand occupational riskin woodworkers. IRCS MedicalScience, 11:216-217.

FRITSCHI, L. \& SIEMIATYCKI , J., 1996. Lymphoma, myeloma and occupation: results of a case-control study. International Journal of Cancer, 67: 498-503. 
GARLAND, F. C.; GORHAM, E. D.; GARLAND, C. F. \& FERNS, J. A., 1988. Non-Hodgkin's lymphomas in U.S. Navy personnel. Archives of Environmental Health, 43:425-429.

GILES, G. G.; LICKISS, N.; BAIKIE, M . J.; LOWENTAL, R. M . \& PANTON, J., 1984. Myeloproliferative and lymphoproliferative disorders in Tasmania, 197280: occupational and familial aspects. Journal of the National Cancer Institute, 72:1233-1240.

HARDELL, L.; ERIKSSON, M .; LEN NER, P. \& LUNDGREN, E., 1981. Malignant lymphoma and exposure to chemicals, especially organic solvents, chlorophenols and phenoxy acids: a case-control study. British Journal of Cancer, 43:169-176.

HARDELL, L.; ERIKSSON, M \& \& DEGERM AN, A., 1994. Exposure to phenoxyacetic acids, chlorophenols, or organic solvents in relation to histopathology, stage, and anatomical localization of nonHodgkin's lymphoma. Cancer Research, 54:23862389.

HARNLY, M. E.; SWAN, S. H.; HOLLY, E. A.; KELTER, A. \& PADIAN, N., 1988. Temporal trends in the incidence of NHL and selected malignancies in a population with a high incidence of AIDS. American Journal of Epidemiology, 128:261-267.

HARTGE, P. \& DEVESA, S. S., 1992. Quantification of the impact of known risk factors on time trends in non-Hodgkin's lymphoma incidence. Cancer Research, 52(Sup.):5566s-5569s.

HARTGE, P.; DEVESA, S. S. \& FRAU MENI Jr., J. F., 1994. Hodgkin's and non-Hodgkin's lymphomas. Cancer Surveys, 19/20:423-453.

HJALGRIM, H.; FRISCH, M.; BEGTRUP, K. \& MELBYE, M., 1996. Recent increase in the incidence of non-Hodgkin's lymphoma among young men and women in Denmark. British Journal of Cancer, 73:951-954.

HOLFORD, T. R.; ZHENG, T.; MAYNE, S. T. \& MCKAY, L. A., 1992. Time trends of non-Hodgkin's lymphoma: are they real? What do they mean? Cancer Research, 52(Sup.):5443s-5446s.

HOLLY, E. A.; LELE, C. \& BRACCI, P., 1997. NonHodgkin's lymphoma in homosexual men in the San Francisco Bay Area: occupational, chemical, and environmental exposures. Journal of Acquired Immune Deficiency Syndromes and Human Retrovirology, 15:223-231.

HOURS, M.; FEVOTTE, J.; AYZAC, L.; DANANCHE, B.; BERGERET, A.; MILAN, J. J.; BONHOMME, I.; FIERE, D.; PHILIPPE, J. \& FABRY, J., 1995. Occupational exposure and malignant hemopathies: a case-control study in Lyon (France). Revued'Epidémi ol ogieet de Santé Publique, 43:231-241.

HUNTING, K. L.; LONGBOTTOM, H.; KALAVAR, S. S.; STERN, F.; SCHWARTZ, E. \& WELCH, L. S., 1995. Haematopoietic cancer mortality among vehicle mechanics. Occupational and Environmental Medicine, 52:673-678.

KOLSTAD, H. A.; LYNGE, E.; OLSEN, J. \& BREUM, N., 1994. Incidence of lymphohematopoietic malignancies among styrene-exposed workers of the reinforced plastics industry. Scandinavi an Journal of Work, Environment and Health, 20:272278.

LANIER, A. P. \& ALBERTS, S. R., 1996. Malignant neoplasms of the lymphatic and haematopoietic sys- tem in Circumpolar Inuit. Acta Oncologica, 35: 601-606.

LA VECCHIA, C.; NEGRI, E.; D'AVANZO, B. \& FRANCESCHI, S., 1989. Occupation and lymphoid neoplasms. British Journal of Cancer, 60:385-388.

LI, F. P.; FRAUM ENI J r., J. F.; MANTEL, N. \& MILLER, R. W., 1969. Cancer mortality among chemists. Journal of the National Cancer Institute, 43:11591164.

LINET, M. S.; MALKER, H. S.; MCLAUGHLIN, J. K.; WEINER, J. A.; BLOT, W. J.; ERICSSON, J. L. E. \& FRAUM ENI J r., J. F., 1993. Non-Hodgkin's lymphoma and occupation in Sweden: a registry based analysis. British Journal of Industrial Medicine, 50:79-84.

LINET, M. S.; MCLAUGHLIN, J. K.; MALKER, H. S.; CHOW, W. H.; WEINER J. A.; STONE, B. J.; ERICSSON, J. L. E. \& FRAUMENI Jr., J. F., 1994. Occupation and hematopoietic and lymphoproliferative malignancies among women: a linked registry study. Journal of Occupational Medicine, 36:11871198.

LINOS, A.; BEARD, C. M.; BANKS, P. M. \& KURLAND, L. T., 1986. Malignant lymphoma in Olmsted County, Minnesota, 1970 through 1977. Mayo Clinics Procedures, 61:706- 713.

LINOS, A.; BLAIR, A.; GIBSON, R. W.; EVERETT, G.; VAN LIER, S.; CANTOR, K. P.; SCHUMAN, L. \& BURMEISTER, L., 1991. Leukemia and nonHodgkin's Iymphoma and resi dential proximity to industrial plants. Archives of Environmental Health, 46:70-74.

LONGO, D. L., 1994. The Palackdharry article reviewed. Oncology, 8:73-77.

LUTZ, J. M. \& COLEMAN, M. P., 1994. Trends in primary cerebral lymphoma. British Journal of Cancer, 70:716-718.

MAIZLISH, N.; BEAUMONT, J. \& SINGLETON, J., 1988. Mortal ity among California highway workers. American Journal of Industrial Medicine, 13:363-379.

MALLIN, K.; BERKELEY, L. \&YOU NG, Q., 1986. A proportional mortality ratio study of workers in a construction equipment and diesel engine manufacturing plant. American Journal of Industrial Medicine, 10:127-141.

MASSOUDI, B. L., 1994. A case-control study of hematopoietic cancers among Kanawha County residents (West Virginia). Dissertation Abstracts. DAI-B 55/ 05, pp. 1821.

MASSOUDI, B. L.; TALBOTT, E. O.; DAY, R. D.; SWERDLOW, S. H.; MARSH, G. M. \& KULLER, L. $H .$, 1997. A case-control study of hematopoietic and lymphoid neoplasms: the role work in the chemical industry. American Journal of Industrial Medicine, 31:21-27.

MEINHARDT, T. J.; LEMEN, R. A.; CRANDALL, M. S. \& YOUNG, R. J., 1982. Environmental epidemiologic investigation of the styrene-butadiene rubber industry: mortality patterns with discussions of the hematopoietic and lymphatic malignancies. Scandinavian Journal of Work, Environment and Health, 8:250-259.

MONSON, R. R. \& NAKANO, K. K., 1976. Mortality among rubber workers. I. White male union employees in Akron, Ohio. American Journal of Epi- 
demiology, 106:284-296.

OLIN, G. R., 1978. The hazards of a chemical laboratory environment: a study of the mortality in two cohorts of Swedish chemists. American Industrial HygieneAssociation Journal, 39:557-562.

OLIN, G. R. \& AHLBOM , A., 1980. The cancer mortality among Swedish chemists graduated during three decades. A comparison with the general population and with a cohort of architects. Environmental Research, 22:154-161.

OLSSON, H. \& BRANDT, L., 1988. Risk of nonHodgkin's lymphoma among men occupationally exposed to organic solvents. Scandinavian Journal of Work, Environment and Health, 14:246251.

OTT, M. G.; TETA, M. J. \& GREENBERG, H. L., 1989. Lymphatic and hematopoietic tissue cancer in a chemical manufacturing environment. American Journal of Industrial Medicine, 16:631-643.

PALACKDHARRY, C. S., 1994. The epidemiology of non-Hodgkin's lymphoma: why the increased incidence? Oncology, 8:67-73.

PARTANEN, T.; KAUPPINEN, T.; LUUKKONEN, R.; HAKULINEN, T. \& PUKKALA, E., 1993. Malignant lymphomas and leukemias, and exposures in the wood industry: an industry-based case-referent study. International Archives of Occupational \& Environmental Health, 64:593-596.

PASQUALETTI, P.; CASALE, R.; COLANTONIO, D. \& COLLACCIANI, A., 1991. Occupational risk for hematological malignancies. American Journal of Hematology, 38:147-149.

PEARCE, N. \& BETHWAITE, P., 1992. Increasing incidence of non-Hodgkin's lymphoma: occupational and environmental factors. Cancer Research, 52 (Sup.):5496s-5500s.

PERSSON, B.; DAHLANDER, A. M.; FREDRIKSSON, M.; BRAGE, H. N.; OHLSON, C. G. \& AXELSON, O., 1989. Malignant lymphomas and occupational exposures. British Journal of Industrial Medicine, 46:516-520.

PERSSON, B.; FREDRIKSSON, M.; OLSEN, K.; BOERYD, B. \& AXELSON, O., 1993. Some occupational exposures as risk factors for malignant Iymphomas. Cancer, 72:1773-1778.

RABKIN, C. S.; DEVESA, S. S.; ZAHM, S. H. \& GAIL, M. H., 1993. Increasing incidence of non-Hodgkin's lymphoma. Seminars in Hematology, 30:286-296.

RIES, L. A. G.; ZAHM, S. H. \& CHESON, B. D., 1994. Non-Hodgkin's lymphoma. In: SEER Cancer Statistics Review 1973-1990 (B. A. Miller, L. A. G. Ries, B. F. Hankey, C. L. Kosary, A. Harras, S. S. Devesa \& B. K. Edwards, eds.), pp. 1-24, Bethesda: Department of Health and Human Services.

RINSKY, R. A.; OTT, G.; WARD, E.; GREENBERG, H.; HALPERIN, W. \& LEET, T., 1988. Study of mortality among chemical workers in the Kanawha Valley of West Virginia. American Journal of Industrial Medicine, 13:429-438.

SANTOS-BURGOA, C.; MATANOSKI, G. M .; ZEGER, S. \& SCHWARTZ, L., 1992. Lymphohematopoietic cancer in styrene-butadiene polymerization workers. American Journal of Epidemiology, 136:843-584.

SCHERR, P. A.; HUTCHISON, G. B. \& NEIMAN, R. S., 1992. Non-Hodgkin's lymphoma and occupation- al exposure. Cancer Research, 52(Sup.):5503s5509s.

SCHERR, P. A. \& MUELLER, N. E., 1996. NonHodgkin's Iymphomas. In: Cancer Epidemiology and Prevention (D. Schottenfeld. \& J. F. Fraumeni Jr., eds.), pp. 920-945, New York: Oxford University Press.

SCHNATTER, A. R.; ARM STRONG, T. W.; NICOLICH, M.J.; THOMPSON, F. S.; KATZ, A. M.; HUEBNER, W. W. \& PEARLMAN, E. D., 1996. Lymphohaematopoietic malignancies and quantitative estimates of exposure to benzene in Canadian petroleum distribution workers. Occupational and Environmental Medicine, 53:773-781.

SCHUMACHER, M. C. \& DELZELL, E., 1988. A deathcertificate case-control study of non-Hodgkin's lymphoma and occupation in men in North Carolina. American Journal of Industrial Medicine, 13:317-330.

SEARLE, C. E.; WATERHOU SE, J. A. H.; HERMAN, B. A.; BARTLETT, D. \& M CCOMBIE, S., 1978. Epidemiological study of the mortality of British chemists. British Journal of Cancer, 38:192-193.

SEOW, A.; LEE, J.; SN G, I.; FONG, C. M. \& LEE, H. P., 1996. Non-Hodgkin's lymphoma in an asian population. Cancer, 77:1899-1904.

SKOV, T. \& LYNGE, E., 1991. Non-Hodgkin's lymphoma and occupation in Denmark. Scandinavian Journal of Social Medicine, 19:162-169.

SMITH, P. R. \& LICKISS, J. N., 1980. Benzene and lymphomas. Lancet, 1:719.

STÜCKER, I.; BOUYER, J.; MANDEREAU, L. \& HÉMON, D., 1993. Retrospective evaluation of the exposure to polycyclic aromatic hydrocarbons: comparative assessments with a job exposure matrix and by experts in industrial hygiene. International Journal of Epidemiology, 22(Sup. 2): S106-S112.

TATHAM L.; TOLBERT, P. \& KJELDSBERG, C., 1997. Occupational risk factors for subgroups of nonHodgkin's lymphoma. Epidemiology, 8:551-558.

THOMAS, T. L.; WAXWEILER, R. J.; MOURE-ERASO, R.; ITAYA, S. \& FRAU MENI Jr., J. F., 1982. Mortality patterns among workers in three Texas oil refineries. Journal of Occupational Health, 24:135-141.

TRAVIS, L. B.; LI, C. Y.; ZHANG, Z. N.; LI, D. G.; YIN, S. N.; CHOW, W. H.; LI , G. L.; DOSEMECI, M.; BLOT, W.; FRAUMENI Jr., J. F.; HAYES, R. B. \& LINET, M. S., 1994. Hematopoietic malignancies and related disorders among benzene-exposed workers in China. Leukemia \& Lymphoma, 14:91-102.

TSONGAS, T. A., 1985. Occupational factors in the epidemiology of chemically induced lymphoid and hemopoietic cancers. In: Toxicology of the Blood and Bone Marrow (R. D. Irons, ed.), pp. 149-177, New York: Raven Press.

VIANNA, N. J. \& POLAN, A., 1979. Lymphomas and occupational benzene exposure. Lancet, 1:13941395.

VINEIS, P., 1996. Incidence and time trends for Iymphomas, leukemias and myelomas: hypothesis generation. Leukemia Research, 20:285-290.

WEISENBURGER, D. D., 1990. Environmental epidemiology of non-Hodgkin's lymphoma in Eastern Nebraska. American Journal of Industrial Medicine, 18:227-235. 
WEN, C. P.; TSAI, S. P.; MCCLELLAN, W. A. \& GIBSON R. L., 1983. Long term mortality study of oil refinery workers. I. Mortality of hourly and salaried workers. American Journal of Epidemiology, 118: 526-542.

WILCOSKY, T. C.; CHECKOWAY, H.; MARSHALL, E. G. \& TYRDER, H. A., 1984. Cancer mortality and solvent exposures in the rubber industry. American Industrial Hygiene Association Journal, 45:809811.

WOLFF S. P., 1992. Correlation between car ownership and leukaemia: is non-occupational exposure to benzene from petrol and motor vehicle exhaust a causative factor in leukaemia and lymphoma? Experientia, 48:301-304

YIN, S. N.; HAYES, R. B.; LINET, M. S.; LI, G. L.; DOSEMECI, M.; TRAVIS, L. B.; LI, C.Y.; ZHANG, Z. N.; LI, D. G.; WACHOLDER, S.; WANG, Y. Z.; JIANG, Z. L.; DAÍ, T. R.; ZHANG; W. Y.; CHAO, X. J.; YE, P. Z.; KOU, Q. R.; ZHANG, X. C.; LIN, X. F.; MENG, J. F.; DING, C. Y.; ZHO, J. S. \& BLOT, W. J., 1996. A co- hort study of cancer among benzene exposed workers in China: overall results. American Journal of Industrial Medicine, 29:227-235.

ZAHM, S., 1996. Non-Hodgkin's lymphoma. In: Cancer-Rates and Risks (National Institute of Health/ National Cancer Institute, eds.), pp. 170-174, Bethesda: National Institute of Health/ National Cancer Institute.

ZAHM, S. H.; POTTERN, L. M.; LEWIS, D. R. \&WHITE, D. W., 1994. Inclusion of women and minorities in occupational cancer epidemiologic research. Journal of Occupational Medicine, 36:842-847.

ZHENG, T.; MAYNE, S. T.; BOYLE, P.; HOLFORD, T. R.; LIU, W. L. \& FLANNERY, J., 1992. Epidemi ology of non-Hodgkin lymphoma in Connecticut. Cancer, 70:840-849.

ZOLOTH, S. R.; MICHAELS, D. M.; VILLALBI, J. R. \& LACHER, M ., 1986. Patterns of mortal ity among commercial pressmen. Journal of the National Cancer Institute, 76:1047-1051. 